Florida International University

FIU Digital Commons

FIU Electronic Theses and Dissertations

University Graduate School

$11-12-2015$

\title{
"The Whole Foundations of the Solid Globe were Suddenly Rent Asunder": Space Place and Homelessness in Poe's "The Narrative of Arthur Gordon Pym" and Melville's "Benito Cereno"
}

Francis H. Hill

Florida International University, fhillo01@fiu.edu

DOI: $10.25148 /$ etd.FIDC000178

Follow this and additional works at: https://digitalcommons.fiu.edu/etd

Part of the Literature in English, North America Commons

\section{Recommended Citation}

Hill, Francis H., "'The Whole Foundations of the Solid Globe were Suddenly Rent Asunder": Space Place and Homelessness in Poe's "The Narrative of Arthur Gordon Pym" and Melville's "Benito Cereno"'" (2015). FIU Electronic Theses and Dissertations. 2280.

https://digitalcommons.fiu.edu/etd/2280 


\section{FLORIDA INTERNATIONAL UNIVERSITY}

Miami, Florida

“THE WHOLE FOUNDATIONS OF THE SOLID GLOBE WERE SUDDENLY RENT

ASUNDER”: SPACE, PLACE, AND HOMELESSNESS IN POE’S “THE

NARRATIVE OF ARTHUR GORDON PYM” AND MELVILLE’S “BENITO

CERENO”

A thesis submitted in partial fulfillment of

the requirements for the degree of

MASTER OF ARTS

in

ENGLISH

by

Francis Harrison Hill 
To: Dean Michael R. Heithaus

College of Arts and Sciences

This thesis, written by Francis Harrison Hill, and entitled "The Whole Foundations of the Solid Globe were Suddenly Rent Asunder": Space, Place, and Homelesness in Poe's "The Narrative of Arthur Gordon Pym" and Melville's "Benito Cereno", having been approved in respect to style and intellectual content, is referred to you for judgment.

We have read this thesis and recommend that it be approved.

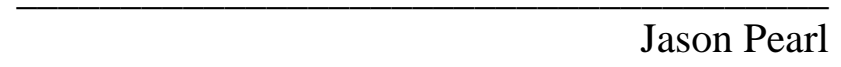

Jason Pearl

Nathaniel Cadle

Bruce Harvey, Major Professor

Date of Defense: November 12, 2015

The thesis of Francis Harrison Hill is approved.

$\begin{array}{r}\hline \begin{array}{r}\text { Dean Michael R. Heithaus } \\ \text { College of Arts and Sciences }\end{array} \\ \hline \begin{array}{r}\text { Dean Lakshmi N. Reddi } \\ \text { University Graduate School }\end{array}\end{array}$

Florida International University, 2015 


\section{DEDICATION}

For Erica. My rock, my solace, my connection to everything meant by "home." 


\section{ACKNOWLEDGMENTS}

I would like to thank my friends and family for all of your support and understanding though times of crisis and times of bliss. You may not have known what in the world I was doing, but you were there for me unwaveringly.

I would also like to thank the faculty that continue to challenge, inspire, and shape me. Thank you Dr. Milbauer for your guidance, mentorship, and for first giving me the chance to meditate on the important connection between place, home, and identity. Thank you Dr. Schoolman for your sage advice, recommendations, all the books you loaned me, and for turning me on to Melville in particular. Thanks to many, many more. Regrettably there is not space enough to mention you all here - but this is a testament to our program! And of course, my immense gratitude to my committee: Dr. Cadle, thank you for planting the seed of material culture in my head, for reminding me that to be a scholar means too to be a writer, for the thorough feedback (not a semi-colon left unturned!), and more than anything, for opening my eyes. As an undergrad, you were the teacher that convinced me to major in English. Dr. Pearl, I am indebted to you for first instilling and then later stoking my thirst for travel literature, unfinished maps, and utopian geography. Importantly, you were the first one to put the idea of grad school in my head, somewhere in the marginalia of an undergraduate paper on Restoration drama. I wouldn't be here without your encouragement. And thank you Dr. Harvey. Your insight and energy continues to motivate my writing and love for literature, as it did even on the darkest days while writing this thesis. Thanks for introducing me to the likes of Wieland and Pym and thereby showing me that American literature is, categorically, absolutely mind-blowing. 


\author{
ABSTRACT OF THE THESIS \\ “THE WHOLD FOUNDATIONS OF THE SOLID GLOBE WERE SUDDENLY RENT \\ ASUNDER”: SPACE, PLACE, AND HOMELESSNESS IN POE’S “THE \\ NARRATIVE OF ARTHUR GORDON PYM” AND MELVILLE’S “BENITO \\ CERENO” \\ by
}

Francis Harrison Hill

Florida International University, 2015

Miami, Florida

Professor Bruce Harvey, Major Professor

My project examines the phenomenon of the hazy spaces on the periphery of the antebellum imagination that, while existing geographically at the very fringes of daily American life, are nonetheless active in the conceptualization, production, and representation of an idiosyncratic American sense of space: an anxiety of spatial fragmentation, formlessness, and modulation. In particular I am interested in Poe's "The Narrative of Arthur Gordon Pym” and Melville's “Benito Cereno,” both of which deal with American transoceanic travel to the proximity of Antarctica and its surrounding seas. These gothicized nautical fictions demonstrate an important dialectic playing out in these extreme spaces: the oscillating experience of external and closed space. What becomes detectable in antebellum literature in which spaces of enclosure interrupt expansiveness are far-reaching, deeply-rooted anxieties of an ever-transforming American space at risk of fragmenting and necessitating reorientation via the sort of imaginary travel texts being examined. 


\section{TABLE OF CONTENTS}

CHAPTER

PAGE

INTRODUCTION: Antebellum America, Sea Travel, and Anxieties of Space ................1

CHAPTER ONE: “The Horrors which Encompassed Me”: Pym and the Spatial

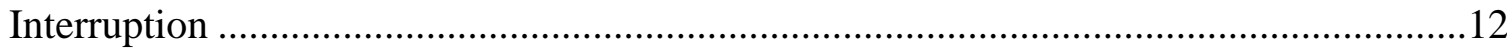

CHAPTER TWO: “Lurking in the Hold”: Space, Place, and the Uncanny in "Benito

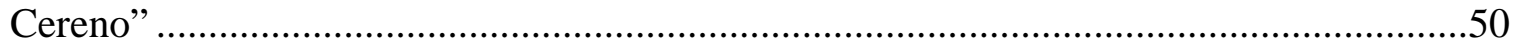

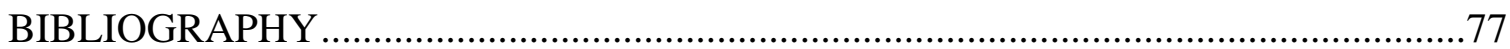




\section{INTRODUCTION}

\section{Antebellum America, Sea Travel, and Anxieties of Space}

The United States of America was a peculiar country to inhabit, discuss, and think about in the early nineteenth century. Despite the perceived ancientness of a topography imagined as rugged primeval wilderness, the region was understood in terms of its newness. Situated in a hemisphere conceptualized in fact as the New World, not only was the landscape devoid of history, tradition, or memory by comparison to the locales whence the English, French, Dutch, and Spanish settlers emigrated, but even those born in the United States had to recognize the fact that the land they called home was amorphous and yet-defined in terms of ever-modulating geographic borders (Baker 1). There was to the American imagination, in short, less a sense of established boundaries than a very real sense of a New World to expand in to - a reality that is reflected by the fact that geographic literacy was a condition for Anglo-American identity (Brückner 3).

To trace the history of the United States is to examine the product of this spatiotemporal peculiarity. The very genesis of the nation is marked by a simultaneity of the new and the very old. Puritan settlers envisioned America in terms intersecting newness and a past immemorial: the "great migration” was a novel experiment, yet one that was believed to be predestined by God. Importantly, the Puritan infusion of new and old was productively conceptualized in a spatial metaphor: the new Massachusetts Bay Colony was to be, in John Winthrop’s words, “like a City upon a Hill,” an image shedding off colonial trappings in favor of metropole (not a colony or settlement but in fact a city) while invoking at the same time natural topographical features (the hill) via the locative preposition upon. Thus, civilization and the contours of the land are not only 
geographically coordinated (even if elevation-wise, civilization comes out on top) but indeed derive their identities from one another. Winthrop’s City upon a Hill may be predestined from the dawn of time, but it only gets its transparency as a sort of harbinger of a new era and model for the rest of the world ("the eyes of all people are upon us") because it is in fact upon the hill, elevated by the landscape as the Puritans are elevated by moral righteousness. This is to say, the city - on its own an unassuming symbol of modernity - gets its newness and its prewritten destiny (something that looks both to Genesis as it does to the future) reaffirmed in its location and interaction with creation in the form of the land and thus with the natural.

Even if 200 years later Americans did not necessarily think of their land and nation as something predestined from creation, they certainly still saw the moment of creation reflected in its place and people. James Fenimore Cooper highlights America's ancient newness, for instance, when he equates the native inhabitants of the New World with the Bible, writing that the attitude and pretentions of America's native populations are "corroborative of the Mosaic account of creation” (Mohicans xxviii). In engaging in this quite typical bit of spatiotemporal distortion - a geographic and chronographic movement across both the wide Atlantic and the long span of time yawning between the recent past of the French and Indian War and the dawn of the universe - Cooper disorients while nonetheless orienting the reader towards an America that is at once very old (primordial, even) and the new kid on the block, as it were: a new entity on the global stage.

The intermixtures of old and new time and space are not the only realities of American life articulated in the seventeenth century still resonant in the nineteenth. 
Many early maps of New England, such as that of John Foster's, the first map printed in the United States, were oriented to the west, anticipating the spirit of westward expansion that would come to define the American identity (see figure 1 below). As the "City upon a Hill" is for $17^{\text {th }}$ century settlers a manifestation of their very destiny, it was America's manifest destiny in the $19^{\text {th }}$ century to extend coast-to-coast, thus hardening and delineating thitherto nebulous and unstable territorial borders. Interestingly, Foster’s map can also be read as a strict departure from the east-oriented T-O maps of medieval Europe. If so, the map itself embodies a sort of double newness as it represents the land as different from the past while it makes the claim that an identifying feature of American space is the existence of unknown spaces at its porous margins (particularly its western one) - defining America precisely by its indefinition and the unknown, or the incompletely catalogued, documented, and mapped space that lies beyond.

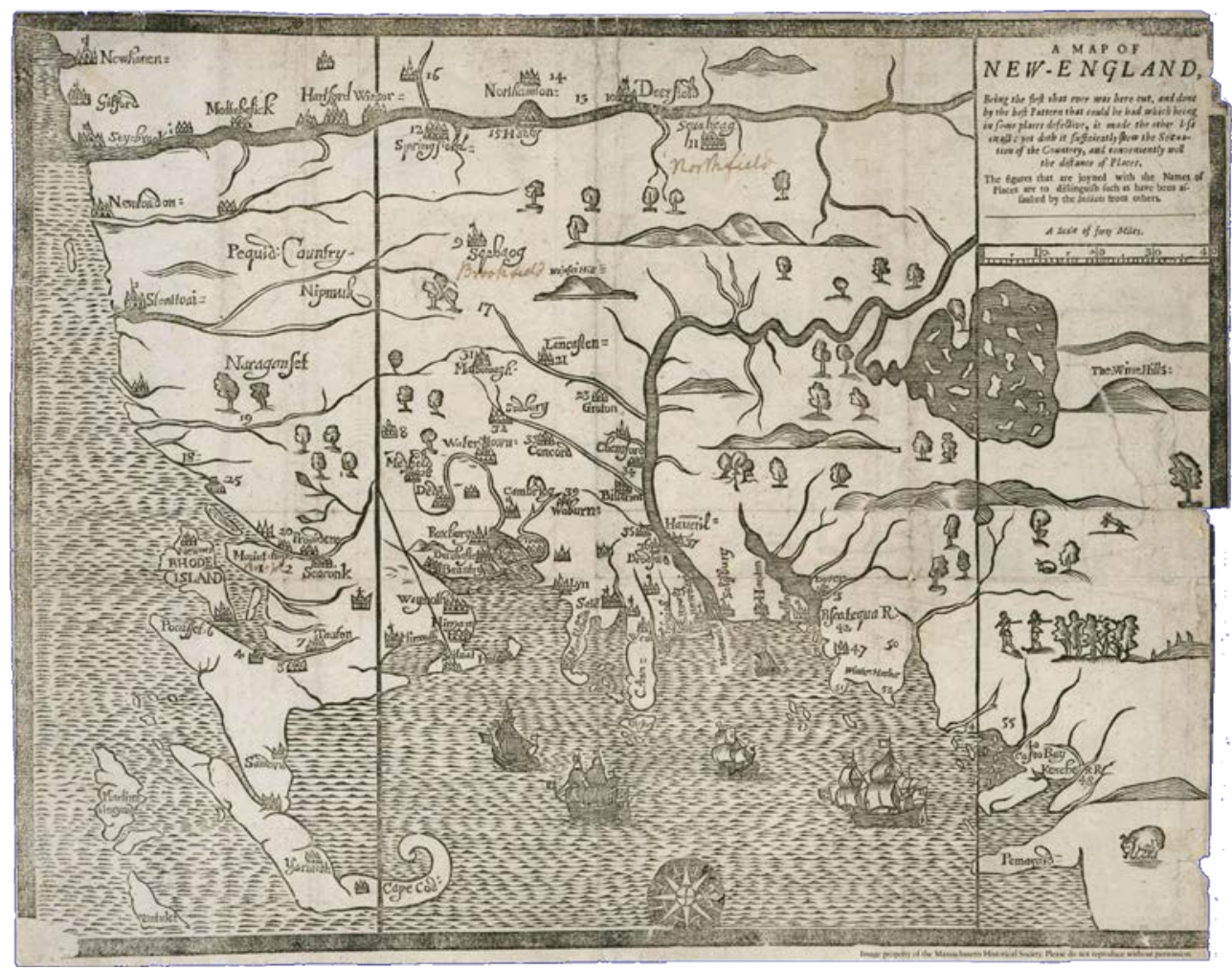

Figure 1. “A Map of New England.” 1677 by John Foster 
This thesis examines the phenomenon of the hazy spaces on the periphery of the antebellum imagination that, while existing geographically at the very fringes of daily American life, were nonetheless metaphysically central to conceptualizing, producing, and representing what I will continue to highlight as an idiosyncratic American sense of space. Recent commentators such as Anne Baker and Hsuan L. Hsu have demonstrated how the unclear and fluctuating edges of the frontier and the spaces beyond shaped the relationship of the subject to the land which the subject identifies as home as well as to the outside world. I explore this phenomenon via a different route, so to speak. Rather than venturing into the conventional continental frontier loci of the American West or any of the contiguous, albeit dynamic, borders and borderlands gained and demarcated by U.S. territorial acquisition, I focus here on American transoceanic travel stretching to the very outer geographic limits captivating the antebellum imagination, to the proximity of a space that, had Joseph Conrad been living in the first half of the nineteenth century, would rightfully be signified when Marlow speaks of "the biggest, the most blank" space on the map: Antarctica and its surrounding seas.

As we will see, an important dialectic playing out in these extreme spaces is the experience of external, open space - that is, the picturesque view from an eminence of a wide sweeping vastness, beholding the sublime and endless ocean - and that of close (and closed) space - the terror and confusion of being trapped in coffins, ship holds, caves, even one's very body. I am interested in what happens when these two spatial experiences collide. I will argue that what becomes detectable in antebellum literature in which enclosure interrupts expansiveness are far-reaching, deeply-rooted anxieties of an ever-transforming American space at risk of fragmenting. 
Spatial orientation is of paramount importance to the American imagination. It is significant, for instance, that the century's single best-selling novel was titled not exactly after its main character but evidently after the dwelling-cum-monument said character occupies: Uncle Tom's Cabin (1852). The immediate associations of home and homeness that may come with the word "cabin," and that we will return to momentarily, are complicated by the narrative and the title's ambiguity. Which cabin of Uncle Tom's is being referenced: Tom's home cabin on the Shelby property in Kentucky, or his unhomelike cabin on the Legree plantation in New Orleans? It would seem the former: in an instance of imaginative spatial transformation, the young Master George Shelby reascribes the late slave's former dwelling as a monument, a cenotaph for the martyr Uncle Tom who met his end in the Deep South at the hands of Simon Legree. But in spite of Shelby's claiming of property in the name of memory and model Christendom, very little of the narrative deals with or takes place in this particular cabin. Rather, much more of Uncle Tom's story (and the most important episodes of the book, to be sure) occur within the prison-like space of the "cabin that had been allotted to him," the one with the "floor . . strewn with weary sleepers, and the foul air of the place [that] almost repelled" even this most steadfast of endurers (406). One place housed the familiarity and comforts of home and family, albeit minus any semblance of stasis as evidenced by Tom's loss of his home as well as its subsequent monumentalization; the other a dynamic place transforming from a gloomy, prison-like location of pain, exhaustion, and hopelessness to the site Tom's spiritual renewal. The ambiguity of the title invites us to look at the plurality of Uncle Tom's Cabins, both of which are in some way in flux. The national bestseller of the age, by its title even, clues us in not only on the importance of space and 
place to the burgeoning nation over which loomed impending crisis, but also the anxieties of a placeness not set or rooted but, on the contrary, able to be transformed, lost, rendered confining, or otherwise displaced. It is likewise telling that the late-seventeenth century's bestselling work of American literature is Mary Rowlandson’s captivity narrative A Narrative of the Captivity and Restoration of Mrs. Mary Rowlandson (1682). In short, American literature starts with spaces and places of restriction, constriction, and confinement, something persisting at least until the space of the United States is fragmented and pit against itself, divided and thought about in the terms of "the North" versus "the South."

I am interested here in two texts by American writers of this period that break the fetters and leave the land of anxietal space for the fluid geographies of the ocean and fardistant shores, for the very antipodes of the United States, even. This paper examines two such travelistic works by prolific American writers: Edgar Allan Poe’s The Narrative of Arthur Gordon Pym (1838) and Herman Melville’s “Benito Cereno” (1855). Each of these works are interesting in how they embody American spatial anxieties within their representations of geographic and experiential space. I argue that the threat of fragmented space, of runaway expansion, of violently tight restriction - of American spatial realities - is not escaped but amplified at the far-from-home high southern latitudes near Antarctica; latitudinally as far from U.S. soil as you can get. Why this physical distance of setting matters at all - why the anxieties are manifest all the more potently via imaginative transportation to exotic, blank, antipodal geographies - is at the heart of the following chapters. 
The sort of reading I propose is concerned with the epistemology and experience of space, place, landscape, site, and bodily space. I lean on insights derived from phenomenology of space, thinking that advocates self-conscious and rigorous interrogation of experience. A phenomenology of space jars us into recognition that the spaces and places that envelope us shape our perceptions, memories, and identities in very real ways; spaces and places are of crucial importance to the being-in-the-world that occupies them, for the being-in-the-world is necessarily a being-in-space. Returning to the idea of "home" raised in the discussion about Uncle Tom's Cabin, a question that arises is how one could explain homeness to one who has never experienced it - or even to someone who has, for that matter. Intuitively, home is more than just a physical site; it is a place, a space that interacts with and shapes one’s own subjecthood, and cannot completely be understood or defined, although it certainly can be (and, for this is how we construct a conception of it, necessarily is) experienced.

Nowhere, perhaps, is the importance of place to subject illuminated more clearly than in thinking about the two connected varieties of what can be thought of as displacement, a "loss of a vital connection to place itself" (Casey xiv): imprisonment (unwilling restriction to a particular place, including importantly the bondage of slavery) and exile (restriction from a particular place). It is telling that historically and currently, displacement is employed as a sort of place punishment, a punishment that is both very severe and, as far as punishment goes, exceedingly common. Severe, because people tend to define their very well-being and happiness - often their identities - by their ability to move or stay (this maneuverability is at the very heart of the intangible, celebrated concept of "freedom," after all), to have a deep-rooted sense of always being "in place." 
Common, because other than penalties in the form of paying money or community service, any sort of punishment that differs too widely in nature from place punishment (such as physical or psychological torture) is often deemed cruel and unusual. Debates about corporal punishment reflect this, although punishment inflicted to a person's material body - the most immediate and intimate location a subject will occupy - might be feasibly considered within the realm of place punishment. The punishment of death, of course, can be thought of as a place punishment in the extreme: banishment from the universe, confinement to nothingness (or another "place," such as hell or purgatory). The particular texts under consideration here, The Narrative of Arthur Gordon Pym and "Benito Cereno," have numerous occurrences of, most noticeably, the first of the two forms of place punishment: restriction to a particular place. Pym finds himself suffocating in ship holds and under earth, as well as trapped on a floating wreck in the middle of the ocean. Those onboard the San Dominick in "Benito Cereno" likewise experience stasis on the sea amidst calm weather as well as the bondage of slavery. But these two texts both contain embedded instances of the other side of place punishment; the restriction not to but from. While neither Arthur Gordon Pym nor Amasa Delano are exiles in the conventional sense, both experience glimpses of metaphysical exile -moments and spaces that serve to keep subjects not so much from an actual physical homeland, but, significantly, from the experience of home and the homelike. The experience of home is the very thing, after all, that makes a home.

When one is displaced, the place in question, intuitively enough, is that of home, with all the solace, comfort, and familiarity that comes with it. Importantly, experiencing this sort of homelessness is not to mourn the absence of the raw, "mere site" that served 
to physically correlate with the "lived place" of one's home (Casey xv); rather it is to be able to recall, but to be unable to regain or again live out, the experience of home. Exilic displacement is, in this respect, the embodied, felt experience of a strangely-present absence, less the non-experience of home than the experience of non-home.

Places, this is to say, are subjective and internalized: I can stand in your house and not experience homeness as you do, and you can be in a zone that I experience as home without experiencing it as such yourself. But just occupying a place that does not project homeness back on the subject is not traumatic. Rather, what I am interested in with this reading are places and spaces that exude the experience of the opposite of homeness: unhomelike or uncanny spaces that not only make transparent, but position front-andcenter, the loss and inability to obtain home or homeness: spaces that serve to displace, to reveal beings-in-the-world as being lost in the world, homeless as far as feeling not at home in the world "without any effective means of orientation in a complex and confusing world” (Casey xv). Philosopher Dylan Trigg writes:

Experientially, the fright [of the experience of the unhomelike] constitutes a moment of apprehension rather than outright terror. The uncanny is strange rather than shocking, weird rather than annihilating. Often, we fail to recognize the power of the uncanny, its workings registered only belatedly and in parched fragments. ... . A feeling of disempowerment occurs. The unity of self-identity becomes vulnerable. No longer do we feel at ease within ourselves. The uncanny leaves us in a state of disquiet, unnerved precisely because we lack the conceptual scheme to put the uncanny in its rightful "place.” (Trigg 28)

Trigg's understanding of the uncanny is an experience of trauma not unlike that inherent in exile. Like being uprooted and forcibly transplanted, to experience the uncanny is to call into question your own identity, or at least to feel as if your identity’s very unity and totality are under assault, however subtly so. Literature dealing with the phenomenon of 
exile presents lives, horizons, worlds steeped in alterity because of the experience of home being out of reach. Spaces of the uncanny/unhomelike are spaces in which the exilic condition is manifest, articulated through aesthetic experience.

In the first chapter I will explore the ways spaces - to be exact, textual space, vast geographies, and spaces of the uncanny - disrupt the unity (or perhaps as we will see, actually serve to construct a unity via an overarching, unifying air of disruption) of Poe's The Narrative of Arthur Gordon Pym. Looking at the generic and formal qualities of the novel - the very fact that Poe is not "at home” writing about the fluid geographies of sea travel and Antarctic expedition - I identify idiosyncrasies that, for some, mar the pages of Pym, such as the transplantation of gothic conventions to the seafaring genre. What emerges is a specific and specifically spatial variety of the experience of the unhomelike, in essence a maritime uncanny, which proves a revealing reflection of a young nation's anxieties over the expanse and limits of its own fluctuating geography and borders. Wide expanses can be just as terrifying as claustrophobic enclosure, and in fact these different spatial modes can and do work in tandem, each amplifying the other's effects, causing a sensation both chokingly restrictive and void-like - a sensation not unknown to an early nation caught between expansion and resistance to expansion.

Next I will turn to "Benito Cereno," a novella that likewise deals with travel from the New England coast to waters of the South Seas, albeit beginning in medias res. Interestingly, all of the same spatial issues are present, the narrative dealing with open-air voyage that is quickly fractured in numerous ways. From the external, unhomelike geography inward to the internal Gothicized features of Don Benito’s ship San Dominick, Melville picks up and runs with the aesthetics of the maritime uncanny crafted in Poe's 
novel to speak to the unthinkability of another uncanny site: revolutionary Haiti.

Relocating the uncanny far-from-home antipodean geography of the blank Antarctic to the black Atlantic - right outside the United States’ threshold, as it were - in effect brings the unhomelike home, enriching our understanding about the contextual relationship between an America on the verge of spatial crisis and the all-encompassing, omnipresent spaces without and within.

Space is the unifying theme in the present study, even if here my methodology depends on a conflation of vastly different scales. The following pages look at far-fromhome geographic space (broad regions, borders, imaginary meridians, coordinates) right alongside the experience of being trapped in a hold or of a body decaying into nothingness, blending larger geographic concerns with subjective phenomenological experience of space. In pushing together seemingly disparate spatial loci, I hope to underscore the ways that these texts reflect an American spatial imagination - an understanding of home and world predicated on spatiotemporal convergence while perpetually oriented toward the unknown at its margins - and how they reveal undercurrents of anxiety and uncertainty about that space's expansion and looming sectional fragmentation. 


\section{CHAPTER ONE}

“The Horrors which Encompassed Me”: Pym and the Spatial Interruption

"The next point to be considered was the mode of bringing together the lover and the Raven - and the first branch of this consideration was the locale.” - Edgar Allan Poe, “The Philosophy of Composition” (1846, original emphasis.)

To start off this study of antebellum American spatial anxieties, I wish to point out up front that Edgar Allan Poe - something of America's poster child for literature dealing in paranoid anxiety - is a highly spatial author. That is, spatial matters, by Poe’s own admission, are central determining features of his aesthetic and his craft. Poetry, Poe argues, benefits by presenting that which unfurls in a "close circumscription of space" (“The Philosophy of Composition” 510), while the brevity of a work’s textual space (poets should figure out early on in a poem's composition its “proper length”) lends the work a "totality" (504) from which it derives its "intensity of the intended effect" (505). Thus, with regards to antebellum American spatial anxieties - reaching back to the colonial captivity narratives and forward to literature proselytizing the abolition of human captivity (that is, literature foregrounding spatiality and spatial limitations) - Poe is a more than aptly suited case study.

What might not seem so obvious at first in my exploration of American spatiality, however, is my choice of Poe text. The Narrative of Arthur Gordon Pym of Nantucket (1838) seems to disrupt both of Poe’s averred spatial limitations in dealing with movement across the globe and in being, after all, Poe's only completed full-length novel. Indeed, the inclusion of the novel in poet W.H. Auden’s 1950 anthology of Poe’s work seems rather unlikely given that Poe's body of work is, otherwise, comprised 
almost entirely of short works. Excluding this outlier, one other novel left unfinished titled The Journal of Julius Rodman (1840), and the lengthy prose-poem “Eureka” (1848), Poe’s letters consist entirely of short poems, short stories, reviews, personal correspondence, and essays. In short, all short: a fact that speaks to Poe's claim that any work that cannot be perused in a single sitting is a work that cannot possibly engender a desired "unity of effect” (Twice-Told Tales, 526). The Narrative of Arthur Gordon Pym, by its very nature as a novel, would seem to violate a central tenet of Poe's own literary criticism.

The novel is, moreover, a curious inclusion in Auden's anthology of the author of “The Raven” and "The Fall of the House of Usher” in that it takes as its subject, in the broadest sense, something that seems intuitively more at-ease in the hands of James Fenimore Cooper than Poe: one young man’s nautical adventures aboard a mutinied whaler, subsequent exploits aboard an Antarctic sealing and charting expedition, first contact with indigenes of the predictably dastardly sort, and a subsequent sweeping southward into uncharted polar seas. Certainly, some of Poe’s contemporaries found the nautical themes and setting an odd match for him. An 1838 review of the novel appearing in Burton's Gentleman's Magazine in Philadelphia describes the work as a clumsy effort, evincing “ignorance in all nautical matters” so egregiously that even "a cabin boy of a month’s standing” would cringe (Frank 265-266). While a survey of reviews reveals that initially there appeared to be a significant number of reviewers duped by Poe/Pym’s claims of authenticity, views on the novel from the early $20^{\text {th }}$ century through 1950 would suggest that the subgenre of high-seas adventure felt "vulgar" to the comparatively lubberly Poe’s pen; it was something of a mere "potboiler that degraded Poe’s best 
talents,” not a successful work, much less a great literary achievement (14) -- when it was even noticed, anyway. Until Auden’s Poe anthology of 1950, The Narrative of Arthur Gordon Pym had largely been ignored by both popular audiences as well as in academics, obscure to the general reader of 1950 and regarded as something of an inconsequential anomaly by critics (Frank 11). To be sure, it had been collected in a few prior anthologies, but only ever silently so for the sake of completion and showcasing aberrant works alongside the more canonical titles. Although Pym has now been a text of interest and significance for more than one third of its time in print, it nevertheless remains an odd fit in Poe's oeuvre in terms of form and of working with conventions dealing with seafaring adventure, form and conventions which Poe himself was not at home with.

It is the not-homeness, or more precisely, the various not-homenesses of The Narrative of Arthur Gordon Pym that I am interested in here, although I am less concerned with contextual questions of the novel as an outlier for Poe than questions of the experience of the unhomelike within the narrative. Broadly, the unhomelike is articulated throughout the novel by movement: not (just) movement across geographic space, but movements between and against differing scales of experiential space. If homeness is stasis and the solace that comes with knowing that one is firmly "in place," so to speak, the unhomeness of Poe's novel is experienced most acutely in the movement between - more accurately, in the violent clashing or collision of - separate spatial modalities. Vast geographies are disrupted by spaces of enclosure in the narrative, and corporeal space ruptures into another type of vastness: that of nothingness and absence. Emerging from these various ruptures is a poetics for a deep-rooted not-at-homeness in space attesting to a reality to which anything like hard or set boundaries is alien. 
In this chapter I will examine the epistemic and experiential problems Poe's novel presents about nautical, far-from-home fictional space, and what insights such a record can offer us for thinking about the early republic: namely, that the American expansionist ethos that is felt so potently in a narrative largely turning on the prospect of pushing further south than any expedition to date into wholly terra incognita is revealed as an epistemology gripped with the threat of fragmentation and dissolution. My project is one of identifying the connection between imaginative movement (fluid and vexed, physical and experiential) and a sense of being in the world likewise susceptible to movement (of borders, of peoples) and fragmentation. To a lesser extent, I will demonstrate the ways the formal, structural, and generic features of the novel interact with the spaces under consideration, as Poe's eschewing of his usual craft-determining principles of totality and unity overlaps in interesting ways with the unfamiliar and uncanny experiences gotten at in the narrative. That is, the long story and the long voyage it documents are similarly disjointed in ways that warrant exploration. I want to suggest in this paper that, far from failing at constructing a "totality" or a "unity of effect," in Pym Poe successfully employs disjointedness to an aesthetic end. That is, the novel is paradoxically structured via moments of destruction, composed around decomposition and extreme fragmentation. The plot's substance is not only destruction and remnants, but void and nothingness. These are real existential and epistemic threats to the antebellum American worldview, a term here intended to be taken in its usual sense (i.e., an antebellum epistemology) as well as a quite literal sense: global aspirations, a view on the world. ${ }^{1}$

\footnotetext{
${ }^{1}$ Pym's publication predates American oversees expansionism proper by over 50 years, but existing concurrently to continental westward expansion is a scientific/enlightenment will-to-map, an intuitive (and even ethical, in keeping with the logic of Manifest Destiny) value placed on the exploration and
} 
Thus, before turning to matters of fictional space and place in The Narrative of Arthur Gordon Pym it will prove illuminating to explore the place of the text: that is, how this narrative "fits" in with contemporary literature in terms of subgenre and general literary preoccupations. Of course, given the flexibility and porousness of any given subgenre, asking how akin or different Pym is to the fare of its day may ultimately be a question of debatable importance (and besides, a solid answer is beyond my scope here). Still, it will nonetheless prove useful to look at Pym's generic and formal features to provide us with a ground, so to speak, for a phenomenological reading of Pym vis-à-vis the conventions Poe's novel engages in, contributes to, and subverts. What comes of the intertwinement of the conventions of the nautical and gothic subgenres with regard to something like an American geographic imagination is important to tease out here, for it offers us a sort of groundwork for detecting an aesthetic quality that Poe operates with in Pym and that Melville continues in "Benito Cereno": an uncanniness rendered all the more uncanny via nautical Gothicism situated not just metaphysically, but physically, geographically far from home. By establishing broadly the conventions I take Pym to work with and within, we will see that Pym presents a poetics of oscillating between (or perhaps more precisely, of alternating collisions or disruptions of) the nautical and gothic aesthetic modes.

Besides the sheer fact of ships and sailing in the narrative - that is, besides the narrative being a nautical-themed work - perhaps the most explicitly nautical literary tope that Pym participates in is that of presenting itself as factual account. I say explicit,

documentation of the entire globe. This is to say, America had a proto-expansionist stake in this sort of expedition; less driven by territorial gain than by gaining an identity, as it were. Lisa Bloom points out in her book Gender on Ice that the fact that polar expedition was indifferent to commercial incentives actually serves to highlight the deep epistemological drive for such enterprise. 
not only because of the conspicuous and near-obsessive attention to details in the narrative - details, such as exhaustive Defoean lists of ship inventory that would prove to be trivial to the point of meaningless in the context of most other subgenres - but because of the admitted importance that the extra-narrative elements of the novel, a preface and an endnote, put on truthfulness and credibility. In the preface, Arthur Gordon Pym explains his initial reluctance in publishing his manuscript stems from the worry that he could not write "from mere memory, a statement so minute and connected as to have the appearance of that truth it would really possess" (43, original emphasis). Such apologies were typical if not required of actual, non-fiction sea narratives: always, the young sailor returned from his first trip worried whether his memoirs written asea would aptly represent maritime labor conditions. ${ }^{2}$ Two years after the publication of Pym, the nonfiction sea-narrative subgenre would be launched into full sail, as it were, by the publication of enormously popular Richard Henry Dana Jr.'s Two Years Before the Mast, in which Dana tells the reader in a preface that he is "unwilling to present this narrative to the public without a few words in explanation of my reasons for publishing it” (37). The reasons, of course, revolve around Dana's desire to offer "an accurate and authentic narrative ... [adhering] closely to fact in every particular, [endeavoring] to give each thing its true character” (38). While front matter bent towards justifying the work is a

\footnotetext{
${ }^{2}$ To be sure, Pym's first appearance in print, the initial serialization of two chapters, was without preface. The novel's preface, published with the full text in 1838, aside from working to coordinate the novel with actual travel texts by being the conventional apology, is an example of Poe's pragmatism in wanting to "float the novel in the manner of Defoe - as authentic record" (Beaver 31), undaunted by the fact that the first two installments were, despite Poe's design, published in the Southern Literary Messenger in January and February 1837 under his own name. The preface as a whole rectifies this: after returning from his journey, Pym tells us, Poe urges the traveler to share his account with the public. Pym declines, but as an alternative Poe suggests he be allowed "to draw up, in his [Poe's] own words, a narrative of the earlier portion of my adventures, from facts afforded by myself, publishing it in the Southern Messenger under the garb of fiction" (44, original emphasis). After finding that the "pretended fiction" of the first two installments were, contrary to Pym's expectations, largely believed by readers as genuine, Pym decides to take the torch and continue telling his story where Poe left off.
} 
longstanding practice in general, especially with regards to works from the other side of the Atlantic, in both of these texts the emphasis on getting it right point towards what Hester Blum identifies as a feature of a "maritime epistemology" in which the intellectual sphere is intertwined with, indeed emerges from, shipboard labor. The textual representation of maritime life to the minute details are symptomatic and productive of what Blum calls the "sea eye," as such details embody the accumulation of sailors' knowledge through the intersection of physical and mental work.

As well as with the non-fictional maritime accounts coming into vogue in Pym's day, claims of factuality are firmly in step with the fictional nautical literary tradition, harkening back to Robinson Crusoe (1719), Thomas More’s Utopia (1516), and beyond. Robinson Crusoe and Utopia invite comparison to Pym now as in Poe's day, as evidenced from notices and reviews of Pym appearing in New York, Philadelphia, and London shortly after its publication commenting on the similarities Pym bears to those potential sources, as well as to the narrative’s fact-presenting ambitions. To be sure, Robinson Crusoe as a source is not very unusual; the $18^{\text {th }}$ and $19^{\text {th }}$ centuries saw the immense popularity of the Robinsonade, an entire genre of Defoe imitation characterized by the detailing of a hero's shipwreck on an uncharted island, said hero's attempts (successful) at survival while there, conflicts with nature, contact with natives, and eventual rescue, almost always all presented as a real account. Pym can be thought of as borrowing most of the elements of the Robinsonade: in first-person narrative, Pym takes to sea despite his parents' wishes, encounters shipwreck, natural dangers, contact with indigenous peoples bent on treachery, all in a narrative presented, however ultimately unsuccessfully, as nonfiction. 
Certainly, a prominent thread running through the critical discourse surrounding Poe’s novel has been the identification of Poe’s sources for writing Pym, sources ranging from fictitious, such as John Cleves Symmes’s futuristic utopian novel Symzonia to factual, such as accounts of Captain Cook, and theoretical, such as the accounts and theories of Jeremiah N. Reynolds. I am not as invested in tracing this lineage as other commentators; the extent to which Pym is a Robinsonade (an imitator of Defoe) or to which Pym is Utopian (experimenting through imaginary space to conceptualize and make manifest Poe's ideological concerns) is not as important for my purposes as is just the sheer fact of Pym's connection to them. Making transparent such a connection serves to situate Pym in a long-running nautical discourse and aesthetic - a literary mode that works, largely, by its investment in either documenting or imagining travels through fluid space. Pym can be positioned within and alongside an established subgenre of nautical fiction because of its dealing with seafaring and navigating, a position reaffirmed in the trope of factual chronicling it takes part of.

Yet, Pym resists strict classification as Robinsonade or mariner literature in general, rather explicitly calling itself into question in such a way that has called some commentators such as Harold Beaver to wonder to what extent Pym was a self-aware hoax, ultimately satiric of the voyage narrative. While embracing with apparent ardor a number of devices already recognizable in the $19^{\text {th }}$ century as nautical, such as the investment in the minutiae of maritime realities, the novel is selective and does away with others. Blum points out that the vast majority of sailor narratives employ a trajectory that starts and ends with the sailor and ship at port (7). On the other hand Pym frustrates this symmetry (while establishing an alternative one via its beginning and ending notes) 
not only by not resolving with the reaching of a final port at the end of the narrative, but by ending abruptly before or perhaps at the exact moment the very object of the latter half of Pym’s voyage - reaching the South Pole - is realized, sans dénouement. ${ }^{3}$

Robinsonades in particular usually end with the happy return of the shipwreck survivor to society, whereas Pym ends with the opposite: a vague notice of Pym’s untimely death.

The connection to Utopia and utopian space is a productive one, even if at first glance there is little utopian about Pym - or at least, there is nothing like a pleasurable, sustained, and static Utopia reached on Arthur Pym’s flight from home into adventure and distant seas. In fact, on hearing his boyhood friend Augustus's seafaring yarns, Pym is attracted less to the pleasurable and romanticized aspects of maritime life than he is the "moments of suffering and despair" that come packaged with life on the sea. Pym tells us:

It is strange, too, that [Augustus] most strongly enlisted my feelings in behalf of the life of a seaman, when he depicted his more terrible moments of suffering and despair. For the bright side of the painting I had a limited sympathy. My visions were of shipwreck and famine; of death or captivity among barbarian hordes; of a lifetime dragged out in sorrow and tears, upon some gray and desolate rock, in an ocean unapproachable and unknown. (66-67)

Even from the very germ of Pym’s journey - the initial fantasies that drive Pym to sea there is no utopian destination perceived (or even desired) at its terminus, no end site of pleasure, but quite the opposite: sorrow, desolation, the unknown. And yet, this isn't

\footnotetext{
${ }^{3}$ Poe writes in his "Philosophy of Composition" that "nothing is more clear than every plot, worth the name, must be elaborated to its dénouement before anything be attempted with the pen. It is only with the dénouement constantly in view that we can give a plot its indispensable air of consequence, or causation, by making the incidents, and especially the tone at all points, tend to develop of the intention” (502). Not only does Pym seem to lack anything like closure, given the serial nature of the narrative's early publication, it is more likely than not that Poe didn't have the "dénouement constantly in view,” which, if we subscribe to his theory, could explain the odd sense of causality throughout the novel, detectable foremost in the novel's disjointedness and repeated disrupting appearances and vanishings.
} 
contrary to the logic of utopian literature. Literary utopias derive their imaginative purchase through "separation ... from the rest of the known world" (Bruce ix). Utopias and it's worthwhile to note etymologically the word is from More's punning on not only eu topos (Greek, good place) but no place - need not necessitate a geographical location at all. This abstraction from geography can be seen, of course, moving forward from More's seventeenth century as utopian literature increasingly becomes less reliant on undiscovered, isolated topos in the remote parts of the world's oceans, rather instead operating via other possibilities, such as future settings. Pym's utopic vision is simultaneously spatial and the no-place gestured at by More's punning. Arthur Pym’s utopia is "separation ... from the rest of the known world" via movement, a utopian ideal perpetually predicated on the idea of flight. Leslie Fiedler's persuasive chapter on Pym in Love and Death in the American Novel argues that it is precisely flight that Pym longs for, harkening back of course to Defoe's Crusoe - flight from family and the demands of domestic life, not out in the world alone but with a likewise fleeing male companion. Regardless (and perhaps because) of the absence of a conventionally static geographic utopia, conceptualizing Pym as a utopian novel makes plain that the novel is one contingent on movement to (and from) places through fluid, imaginative space.

However, even if one takes utopia to be a concept that can be distilled to the microcosmic and mobile (read: rootless, placeless, one always in motion, perpetually in a sort of voluntary migration) society engendered by homosexual companionship as does Fiedler, any and all of these mobile microcosms are frustrated and short-lived before failing, and always violently so. Pym's first taste of the freedom and adventure that comes with responsibility-fleeing male companionship is ruptured, quite literally, when 
Pym and Augustus's sailboat the Ariel is slammed into and rent asunder by the whaleship Penguin, an episode not only anticipating a number of other huge collisions and rendings asunder throughout the novel, but that will be echoed again in other male-male floating societies in miniature: Moby Dick's destruction of the Pequod and, nearly a half-century later, Huckleberry Finn and Jim’s raft being split apart by a steamer on the Mississippi. Pym's second utopian attempt at escaping society out on the open sea with Augustus winds up in extreme and disorienting imprisonment in the Grampus's hold, violent mutiny and shipwreck, Augustus's eventual death, and Pym’s former companion’s body decaying and falling apart before his very eyes. Later, on the far-off fictional island of Tsalal, utopia via male companionship (now with the repentant mutineer and half-breed Indian, Dirk Peters) is threatened while the physical landscape of the dreamlike, antipodal would-be Utopia is ripped apart by a mechanism of the deceitful natives that causes an artificial landslide. Pym's flight sustains utopian fantasy in a very real sense; otherwise, anything and everything verging on utopian - anything predicated on a sort of pleasure derived from nautical geographic movement or male-male anti-domestic companionship in fluid space - is disrupted time and time again throughout the narrative. It is these moments of interruption that I will focus on throughout the remainder of this chapter, interruptions that not only stall physical movement through space as well as dispel moments of utopian experience, but threaten the very identity of the subject via violent shifts in spatial scale that, like Ishmael's potential for slipping from the rigging on the Pequod, cause one's “identity [to come] back in horror” (Moby-Dick 158-159).

Pym has a recognizable foot in the nautical literature of Defoean/Utopian tradition, but, like Ishmael ascending the mast, upon closer inspection, it is not a very 
solid footing at all. While it freely experiments with the conventions of the broad nautical subgenre, those same experimentations cause it to resist being unequivocally situated or classified as something recognizable as such. Pym is a work of the mariner literature that was in vogue during its day, complete with traceable connections to important predecessors, but at the same time it willingly steers towards and beyond the margins.

It is important to note here that The Narrative of Arthur Gordon Pym is not Poe's only work dealing with sea voyage. Together with "MS. Found in a Bottle” (1833) and “A Descent into the Maelström” (1841), the three form what is referred to by readers of Poe as the "salt water trilogy” (Frank 19). Poe’s “The Oblong Box” (1844) again takes up voyage, and "The Premature Burial” published the same year culminates in the narrator's waking from a nightmare to find himself not prematurely interred as he dreamt but rather in the sleeping berth of a small boat. This last story gets at a recurring theme familiar to Poe, and one that certainly ran through Auden's Poe anthology (perhaps being the most immediate uniting factor qualifying Pym for inclusion): that of living inhumation. The threat of being buried alive (or walled in, in the case of "The Black Cat" [1843] and "The Cask of Amontillado" [1846]) is found in "Berenice” (1835), "The Fall of the House of Usher” (1839), and in a way “The Tell-Tale Heart” (1843). Poe’s call for the necessity of "close circumscription of space" is taken to its extreme in Poe's claustrophobic, coffinlike spaces. A possibility is that, rather than being a personal obsession of Poe, the recurring inclusion of the trope of vivisepulchre is indicative of the author's shrewdness at capitalizing on a collective popular phobia of premature burial shared by collective American readers in the early nineteenth century so he could sell his work. By the same logic, Poe's choice of sea narrative for Pym and his other nautical tales might also have 
been an act of opportunistic interestedness - a cashing in on the recent popularity in travel literature - in which case Pym, featuring prominently sea exploration as well as the threat of living inhumation, might be considered to be tailor-made for the popular taste of readers. Indeed, its full-length publication was delayed to coincide with the highly publicized Wilkes Expedition of the Antarctic (Giles 138). If so, important is not the mere fact of Poe's shrewdness - that he had his finger on the pulse of his readership, as it were - but rather what it was that pulse said: that American readers were preoccupied with, among other things, both expansion and interment. Travel literature and the threat of burial seem to be simultaneous American preoccupations; nineteenth century Americans, it seems, were captivated by expansiveness and movement through and mapping of wide-open fluid space as well as phobic spaces of deathly enclosure.

Of course, death and spaces of confinement call to mind another aesthetic, a subgenre for which Poe is an instantly recognizable figure and one that historically, at least at important times, has also engaged in the trope of parading as fact: the gothic. Horace Walpole's The Castle of Otranto (1764), typically identified as the first gothic novel, was billed by the author as a found document (Frank \& Hoeveler 12). Pym's fictional claim of truth, as well as the sense of foundness (and lostness) gathered from the ending Note by a nameless commentator telling of Pym's death and three missing chapters, works alongside other familiar gothic elements - namely, the unfamiliar - to orient the narrative toward the gothic aesthetic.

Both the preface and the endnote explain their inclusion in the publication by referencing some untold accident: in the preface the reader is told that it was "accident" that "threw" Pym into the company of Poe (51), resulting in the telling of the narrative, 
and in the endnote an unnamed commentator tells us that it is an accident that takes Pym's life as well as his last chapters, removing any possibility of the narrative's closure. The respective accidents at the start and end of the novel, then, actually start and end the novel: accident gives rise to the narrative being published and another accident stops the narrative abruptly. Unknown events propel and finally halt the novel; undefined circumstance defines Pym's form. The unknown and the inescapable feeling of helplessness engendered by unknown forces, rather paranormal or clandestine, is Gothic in and of itself. For instance, helplessness reverberates through the first American Gothic novel, Charles Brockden Brown's Wieland; not only is the book about the hearing of strange voices, like Pym, the action of the novel begins with an accident: the elder Wieland's first exposure to the germ of fanaticism is when his eyes happen to land on a book that has been left open by happenstance. Strange causality abounds in Pym as well; not only is the narrative disjointed and episodic to the point of being read by scholars such as Walter Bezanson as several discrete short stories, things tend to appear and vanish just as easily. I will revisit the compositional and material idiosyncrasies of the novel shortly.

It is important to note that both the travelogue and the gothic are literary modes inherently operating through the spatial - movement through and across vast and fluid space (be it raw homogenous geographies or oneiric, utopian fantasy-space) in the former, and the dense, memory-laden or haunted spaces of affective enclosure (as well as, for the Radcliffean Gothic, the experience of sublime topographies) in the latter. In Pym, these spatial strata - expansive geography and the threat of chocking restrictiveness (what for our purposes can be usefully, if simplistically, reduced to nautical and gothic space 
respectively) - do not blur together imperceptibly as much as violently clash together, one aesthetic mode and experiential modality disrupting the other in a way that gives rise to a radical unsettling; a potent out-of-placeness jeopardizes one’s being-in-the-world all the more because of its nautical setting, a setting characterized largely by vast nothingness, by restriction amidst limitless expansiveness: the maritime uncanny. ${ }^{4}$

It will be useful to take a look at Pym's form alongside of what emerges in this interplay. While it may, on first consideration, seem like there is nothing interestingly spatial about a piece of literature (as opposed to, for instance, the much more explicitly spatial visual arts of paintings, photography, theater, or film), an understanding of space and place in Pym benefits exceedingly by a consideration of the spatiality or form of the material artifact. This is to say, not only are the spaces in the text interesting, but so is the space of the text, perhaps rendered all the more so in the case of Pym as nautical and gothic modes both privilege the materiality of a text in the guise of the found document. ${ }^{5}$

\footnotetext{
${ }^{4}$ It should be noted that there are other instances of texts that fit the nautical travel gothic scheme outside of Poe and Melville. The anonymous The Female American (1767) is a Robinsonade with noted gothic elements (see Nordius, Janina. “'Thus Might I Reason with a Heathen...': The Gothic Moment in The Female American.” Nordic Journal of English Studies: NJES 7.2 (2008): 1-18). Mary Shelley's Frankenstein (1818), at least with regards to the framing narrative, invites comparison in a number of ways. Beginning the same year as Pym's publication, influential nautical author Frederick Marryat's gothic novel The Phantom Ship (1839) began serialization; it is remembered today as a failure.

${ }^{5}$ An interesting alternative path to take in reading Pym spatially would be to look at the space of the pages of the Messenger, looking at what was published along with and adjacent to Pym in the issues in which it appeared. Poe was the editor of the periodical when Pym ran, so it could be interesting twice over to think about the editorial decisions he made, namely what he chose to print alongside, indeed adjacent to, Pym. The fact of Pym's serialization could also give us an insight of a different sort through highlighting, for one, the infrastructure of the print culture of its era, demonstrating an antebellum American spatial imagining in terms of the Andersonian imagined community - the space of Antebellum America as nation. For two, serialization emphasizes the labor involved in writing a novel in the way a self-contained novel doesn't: it makes transparent the temporal dimension of writing that is easy to forget when a new, complete, closed-off novel appears on the scene. The novel-as-product of labor could very much be of interest with regards to the lens of maritime fiction.
} 
The novel's structure - that is, a violently fluctuating yet symmetrically organized structure - thematizes Poe’s poetic scalar dynamic of experiential space.

Pym's composition upsets a typically nautical, port-to-port structure, while at the same time it is organized via a strange sense of causality, its form delineated by unexplained accident. A striking characteristic of Pym is that the novel is a highly structured work despite its jarring non-conclusion and ending open to speculation. Bezanson was the first to point out that the narrative is not so much a complete novel as it is a narrative consisting of discrete episodes - four short stories - corresponding to the four discrete vessels Pym sails in. John Barth and Richard Kopley have since drawn conclusions of a deliberate, well-plotted work from the novel's structure; far from evidencing an imperfect, incomplete, or abandoned work, Barth notes the work’s order and symmetry, the action being "smack on the equator of the globe smack at the equator of the story" (Barth 228). Kopley further makes plain the symmetry, drawing parallels between the catastrophic accident in the first chapter and the apocalyptic last chapter. Space in the text and the space of the text, in any case, correlate in a systemized way, and despite avoiding the port-to-port schema (and logic) of the sort of travel narratives serving as Poe's sources, the novel contains a symmetry of apocalyptic disaster, a systemized chaos of destruction and strewn raw material.

Like Poe's Eureka, the "prose poem” in which the author waxes philosophical on the nature of matter (the word "atom" appears over 100 times in the poem, the word “particle,” 73), Pym is a work with a lot of debris. Ships tear through boats, cargo gets entirely upset into chaotic ruin in its hold, the bodies of seamen are butchered, vessels become floating wreckages in storms that carry away their masts, rotting bodies fall apart 
or are torn apart by carrion birds, mountains are unearthed - physical material becomes as thoroughly fragmented as the space enveloping it in Pym. Like the raw molecules and particles in the narrative, the narrative itself works via shattering moments of collision both physical and phenomenological. When the Penguin smashes into Augustus's boat the Ariel, tearing it to shreds, this crisis sets the tone for the rest of the narrative, the first collision of many. The next collision is the collision of gothic and nautical space: the collision of separate spatial scales.

Poe’s investment in the horrors of claustrum have been alluded to above. It is a telling feature of the novel that Pym's setting sail is phenomenologically frustrated as it occurs - a frustration that is, significantly, the beginning of Pym’s long voyage. Just as Pym’s journey starts - just as geographically Pym’s material self is being transported, like Melville’s Pequod later, out of the familiar harbor of Nantucket and into a vast and boundary-less nautical world - in a surprising subversion, Pym’s experiential horizons are completely abstracted from the trajectory he is tracing. Rather, his can only be traced out a few cramped feet in any direction: Pym is confined in a coffin-like shipping container deep within the dark and labyrinthine hold of the ship. Transported like so much cargo, Pym is subjected to a manifold out-of-placeness engendered by the disorienting setting (not only in a box with nearly the dimensions of a coffin, but in a black hold with gloomy “windings innumerable” [74]), the near-absence of external stimuli (Pym can “distinctly [feel] the brig in motion” [73] even if he cannot see it), and the knowledge that he is traversing space, that Arthur Gordon Pym of Nantucket will emerge from the hold somewhere completely different from his place of origin. 
It is in this confused state that he slips into a Van Winklesque slumber, waking up to his stored meat gone putrid and his only implement of discerning anything about his voyage - his watch - run down. Yet, although he has no idea of the goings-on without (an ignorance not unlike Melville’s Amasa Delano’s that will ultimately preserve him from the black mutineer's axe), there is nonetheless a striking similarity in what Pym can see from his interior space within the hold to what Pym would see on deck. Whether on deck or below, there would not be much for Pym to look at. Blum points out that novice sailors were often surprised at the monotony of life at sea (6). The comparison would be strengthened, too, if like below deck, on deck Pym had no necessary labor to attend to. On deck as a passenger, Pym - not the experienced navigator nor a common sailor "before the mast” busy with maritime labor - would have little with which to orient himself.

The difference is that below the deck, Pym's trajectory through fluid, vast, homogeneous space is not available to him, except for the "distinct" feeling of the brig in motion. In the hold, not able to witness the journey he is partaking in, Pym busies himself by reading about another journey, that of Louis and Clark's westward expedition into newly acquired territory and beyond, to the very limits of the continent. Not entirely privy phenomenologically to the event of his own journey, Pym supplements the experience with a surrogate of sorts, another journey supplanting his actual motion as intentional event. Put another way, Pym must turn inward to conceptualizing imaginative traverses in order to feel his own. Even from the outset of his journey, Pym is already experiencing phenomenological crisis via the substitution of one intentional object for another to complete the totality of experience. 
The conflation here of a landmark, highly symbolic westward overland journey with the routine launching of a civilian brig from Nantucket for capitalist ends demonstrates the extent to which even sailing for personal profit could be couched as national project: the dealings of merchant ships not only served as the foundation of the economy in the first half of the $19^{\text {th }}$ century; they linked the United States to the rest of the world. Through Pym's phenomenological substitution, in an imaginative transformation and transplantation, the unsettled continent becomes the Atlantic Ocean and vice versa. This distortion is simultaneously disorienting as it orients, indicative of the importance of maritime industry to the young republic and the global economy (Blum 25). Tellingly, a particular (if not peculiar) maritime commerce is implicated via Pym’s enclosure in motion, one having been outlawed for thirty years but still resonating, embodied in memory. Rather than feeling small amidst the vastness and nothingness as he would on deck, smuggled in the hold, Pym's body feels confusedly oversized in the small space containing him. His bodily identity is threatened either way, but is under a sort of double jeopardy because of the spatial scalar dynamic at work, a gesture echoing the transatlantic trafficking of African slaves, a thoroughly havocking doubled displacement, a place-punishment par excellence combining uprootedness from a homeland with the bondage of imprisonment. Although Pym's enclosure is by no means as horrible as the sort the African slave experienced en route in the Middle Passage, Pym's blind arc through space in a container at least calls to mind the anti-homeness of chattel slavery, in which corporeal experiential space becomes commodity, mere materiality, rendered one object among others in the world. 
The gloomy ship hold comes with all the trappings of the Gothic, something we will see repeated with Melville's San Dominick and the lurking mysteries within that ship’s hold. Windings are innumerable and pitch black, meat transforms into putrid flesh, secret messages have to be decrypted, and something like a terrifying monster materializes as if out of Pym's night terrors. The “beast” proves to be Pym's canine companion Tiger, smuggled on board by Augustus, a moment of solace and familiarity of "a giddy and overpowering sense of deliverance and reanimation" that causes "the long oppression of [Pym's] bosom” to be relieved in a flood of tears (77) - in an otherwise unhomelike totality. Of course, this homeness is temporary, dissolving confusedly when either "the want of water or the confined atmosphere of the hold [drives Tiger] mad” (87-88, emphasis mine). The hold is an uncanny, unhomelike, anti-homelike space to the degree that any and every homelike experience there within is transmuted into the utter opposite - the confinement changes Pym's friend and connection to home into that which threatens Pym’s very existence.

In this uncanny and defamiliarizing hold, Pym's sleep is as troubled as his waking. After his prolonged, confused Van Winklean sleep, Pym endures another "tedious twenty-four hours" in his coffin (again, in which he can feel the pitch and roll of the Grampus "far in the main ocean”) before falling asleep again. In his sleep, the dynamic of confinement amidst movement is actualized in a dreamscape. Pym engages in quick successions of travel across space and against spatial scales, an articulation of the spatial interruption that Pym is experiencing in the hold and will experience throughout the narrative: 
My dreams were of the most terrific description. Every species of calamity and horror befell me. Among other miseries I was smothered to death between huge pillows, by demons of the most ghastly and ferocious aspect. Immense serpents held me in their embrace, and looked earnestly in my face with their fearfully shining eyes. Then deserts, limitless, and of the most forlorn and awe-inspiring character, spread themselves out before me. Immensely tall trunks of trees, gray and leafless, rose up in endless succession as far as the eye could reach. Their roots were concealed in wide-spreading morasses, whose dreary water lay intensely black, still, and altogether terrible, beneath. And the strange trees seemed endowed with a human vitality, and waving to and fro their skeleton arms, were crying to the silent waters for mercy, in the shrill and piercing accents of the most acute agony and despair. The scene changed; and I stood, naked and alone, amidst the burning sand-plains of Sahara. (76)

Pym's dreams are of extreme confinement to the point of being smothered to death, giving way to expansive vastness of sublime proportions. Animated trees, giant and "endowed by human vitality" spring forth from the desert as a testament of the uncanny, resolving with isolation in utter expansive void.

Pym's “premature interment," as he thinks of his episode in the hold (80), is “close circumscription” to the extreme - namely, the limits of traversable space being made to match precisely the limits of the subject's bodily space. When Pym is buried alive or trapped, or when bodies are disintegrating, being butchered, or otherwise torn apart - to use Poe's own philosophy of composition, when the "circumscription of space" defining the "insulated event" is the very limits of the body - the form of the narrative aligns, focuses, locks in with, that which is formalized in the narrative. The compositional elements become part of what Poe calls the "frame to a picture," the picture here being the intimate space of the body. Thematized by Pym's nightmare, even in spaces of no space, spaces of absolute enclosure, spaces of embodiment, Pym is not hermetically sealed off from the world. On the contrary, his corporeal being is framed, 
focused, attended to by the circumscription, and as such his very self projects outward, disrupting the concentric spheres enveloping him, until Pym is lost in a vast and vacuous waste - the world. Space is fragmented to the point that it erupts outward, to the point that spatial scale isn't even a conceivable fiction. This is the poetics of a nation stuck between expansion and fragmentation, a nation with a single solid border - the Atlantic coast - interestingly not solid due to the human cartography striving to reconcile the nation's other borders but due rather to the contours of natural topology. This single solid boundary is, paradoxically, the permeable and traversable sole link, via nautical industry, to the rest of the world, simultaneously existing in the American imagination as a temporal threshold as well: the link to the Old World from which Anglo-Americans originated.

It is significant that the gothic moments of the narrative are often situated within the nautical, in terms of the gothic episodes being part of a broader adventure novel (that is, in terms of narrative, textual space), as well as in terms of the gothic playing out in circumscribed spaces of confining anxiety within larger, nautical space. At times throughout the novel, typified perhaps by the hold episode and reaffirmed in Pym's nightmare in which movement from extreme confinement to extreme expanse happens in an instant, there are concentric circles of space, starting with the body, pulling back into the enclosed or gothic space, then further into the enveloping nautical space. The gothic punctuates the narrative in ways that correspond to the experience of space. It is this very sort of spatial dynamic at work - the modulation and interplay between wide-open spaces and the claustrophobic spaces of trauma and anxiety - which makes visible that the narrative operates through what I've been calling spatial interruption. The narrative is one 
in which the threat of the world closing in on the body, or opening up to leave the body stranded and lost in space, is always implied, jeopardizing the subject's existence.

As with Pym's hold confinement, often enough the spatial interruption is a gothic interruption, junctures when the gothic pierces the broader narrative. But, significantly, the spatial interruption need not always and explicitly be couched in the trope of entombment or labyrinthine space. The confinement of a person - the very removal of something integral to subjecthood - can and does occur in the wide-open expanses of the sea, such as amidst wrecks, calm weather, or being surrounded by ice. The phenomenon of being confined in open space will be explored in the next chapter. Here it is worthwhile to turn to the maritime uncanny likewise unchained from the gothic. The maritime uncanny manifests in the high southern lattitudes as it appears increasingly in the very materiality of the narrative. Pym's form becomes as unmappable, disjointed, and disorienting as the space he explores.

Pym's tenure both in the hold and waiting for death or rescue aboard the wreckage of the Grampus are a keen demonstration that those spaces that have the highest capacity to surprise the subject do so via a breakage in the experience of time that ultimately foregrounds the space itself. As Pym journeys farther from home to more extreme latitudes, his experience of time is likewise disrupted further, and in ways different from the interminable days confined and adrift. An explicit distortion in time and space appears, fittingly (to the extent of which we will discuss further below) in a footnote. The footnote in question is at the opening of chapter 18, the chapter in which the Jane Guy first makes contact with Too-wit and the natives of Tsalal. The first half of it reads: 
The terms morning and evening, which I have made use of to avoid confusion in my narrative, as far as possible, must not, of course, be taken in their ordinary sense. For a long time past we had had no night at all, the daylight being continual. The dates throughout are according to nautical time, and the bearing must be understood as per compass. (194, original emphasis)

Philosopher Dylan Trigg specifically gives the example of the oddness of no sunset to exemplify the sort of uncanny feeling a frustrated space-time experience can leave imprinted on the memory (8). The author's footnote, an aside about the oddities of the locales Pym has visited “for a long time,” is suggestive of seized time, "the daylight being continual.” At the same time it indicates a vexed linkage of place and memory, granting Pym's reportage of his journey to exist as a sort of surrogate for what we think of as memory proper, the physical artifact of the novel being the vessel for the memories of Pym's account. If we allow the text to be a sort of embodiment of memory, we see interesting developments to the application of Trigg's phenomenology, especially considering this footnote highlights the very slippage inherent in observation, documentation, memory, and reportage.

This first part of the footnote, whether an afterthought on the part of Poe or not, lends credence to the narrative by the very device of admitting that the narrative takes license with its reporting of Pym's experiences. The crew is positioned in a disorienting although wide-open space south of the 83rd parallel in which the sun doesn't set or rise, but just hovers around the horizon. And yet, Pym speaks of it being “morning” even while acknowledging this impossibility, if we take morning, as Pym clearly does intuitively, as signifying the first half of the day encompassing the movement of the sun to its zenith. This taken-for-granted, roughly vertical movement of the sun's arc is, rather 
literally, turned on its side in this uncanny geography. We can understand Pym to hold the conventional, sun-oriented sense of what he takes morning to be by his contrast to night. "For a long time past we had no night at all," he reports in the footnote. For Pym, then, "night" is not the word for the rough sixteen hours bisected by and symmetrically flanking the change of calendar day; night has very real connections with, indeed depends on, the sun and absence thereof. In the middle of the Antarctic summer (January), day is perpetual, so it doesn’t make sense to speak of night. By this very heliocentric logic it makes just as little sense to speak in terms of morning and evening, but this is precisely what the narrator does in order to “avoid confusion.” In both the geographic and narrative space, then, confusion can be avoided, by misrepresentation and by using idioms of impossibility (the very things one would think engenders confusion), deliberately and admittedly meant to be understood contrary to their “ordinary sense.” Like within the unhomelike hold of the Grampus, Pym orients himself to what is not observationally present in a manner to cope with the uncanniness of his surroundings.

How does one map the uncanny? Here Pym can be understood as imposing the unnatural demarcations of morning and evening on the geography around him, an imposition of a man-made order that renders reality measurable, thus more understandable, even while pointing away from or misrepresenting reality. Pym strives to make the unfamiliar familiar (in the next chapter we'll see Melville’s Captain Delano engaging in a similar undertaking aboard the San Dominick), to reconcile the uncanniness of the far-from-home geography via a more home-like and thinkable frame of reference, which in turn only serves to reinforce its uncanniness through the piling on layers of familiarity and alterity. Recognized, recognizable devices - far from taming or 
making recognizable, far from familiarizing - rather enhance the strangeness of the unrecognized place, render it more unfamiliar. It is my suspicion that the project of surveying and mapping newly acquired territory had a similar effect on one's understanding of the United States: the more one tried to understand and thereby tame one's dynamic, modulating space, the more one was aware of that dynamic, that modulation and the more one was familiar with the very fact of America's unfamiliar form.

Defaulting, as here, to understanding the world in terms of an order-giving construct speaks volumes about a pervasive desire for imposing order over the world the self-same desire driving expedition and the mapping of unmapped space. But that Pym does so despite the information available to his immediate senses, ultimately choosing an abstracted system over that which is observationally and experientially present (echoing, in a way, Pym's consciousness of the Louis and Clark expedition during the opaque genesis of his own), on one hand, raises questions about Poe's attitude about the sovereignty of empiricism. Simultaneously, this first half of this footnote reveals an uncompromising desire to be able to measure, order, and make sense of the world, while denying that faculty to the methodology celebrated for its utility in doing so. On the other hand, Pym's dogmatic orientation towards constructing order despite that which is available antagonizes the ideological structures at work. Here I am speaking of Pym's empiricist spirit in relation to his uncanny surroundings' affect - via the experience of a sequence of places all in large part divorced from familiar structures of experienced time. Even if we distance ourselves from the experiential aspects of time and divert our attention to the logical, a priori structure (that is, here maintaining definitions 
of evening and morning that have nothing to do with the apparent experience of a rising and setting sun; rather, that there is nothing inherently perverse or telling about bracketing off the first 12 hours of the 24-hour day as morning regardless of latitude or the sun's location relative to the horizon, and that following nautical time for expediency is less demonstrative of a will-to-order than, say, an alternative of devising a system or set of categories that matches [or projects itself onto] the surrounding landscape) it is nevertheless the case that "time" in this respect is revealed as ultimately and profoundly arbitrary. When we speak of time in the objective sense, what is being measured is Earth's revolution on its axis, but this measurement is always in terms to the planet's relation to the sun, barring of course time measured by chemical and molecular deterioration. Taking the sun and its role out of the equation for measuring time serves to highlight the practice as a construct, an abstracted and arbitrary mechanism for keeping order; ultimately, it is another human coping mechanism to deal with the absurd and the uncanny. In this light, the scientific, supposedly un-affective aspects of time are still rooted in experience and still, above all, human and visceral - a survival tactic, a way of fighting back against the observationally present forces of the unhomelike. In this respect, both experiencing the unhomelike space as well as likewise the act of mapping said space through the mathematics available to Pym lays bare a deep, unsettling fact contrary to human intuition. With even time deconstructed, Pym is lost in a void-like world.

Pym's aside about the absence and arbitrariness of temporal indicators is fittingly delivered as, of all things, a footnote. Footnoting, intuitively, is symptomatic of the (unfamiliar) longer form that Poe is engaging in here. It is still the case that the insertion of a footnote breaks the unity of the text to some degree, however marginally. The reader 
of the text is snapped out of the experience of the text momentarily only to be reminded that this text is just that - a text. Such footnotes point to the work as a work, and certainly in this example the fourth-wall-breaking language of the footnote deviates markedly from the journal-entry format of the text it is annotating. Any generalizations aside, it is extremely appropriate, that the aside that almost singlehandedly points to the uncanniness of polar latitudes while complicating the text by upsetting its sense of memory and reportage is delivered in the form of a break from the narrative itself. This is to say, space and time being disrupted within the novel is also space and time disrupted on the page.

The footnote continues to destabilize not only the uncanny polar space, but retroactively all the geographic spaces hitherto told of in the narrative as well as the space of the narrative itself even while serving to make the text more believable as report: "I would also remark, in this place, that I cannot, in the first portion of what is here written, pretend to strict accuracy in respect to dates, or latitudes and longitudes, having kept no regular journal until after the period of which this first portion treats. In many instances I have relied altogether upon memory” (194).

All along Pym has taken great pains to provide geographic coordinates down to minutes of degrees, as well as compass bearings, temperatures of water and air, and the direction the ship is heading in degrees of variation per azimuth. It is without a doubt in line with the conventions of maritime writing to incorporate detailed nautical jargon in re-presenting the labor involved in sailing and navigation. Yet, here Pym admits that, for a portion of the narrative anyway, dates and navigational data have been recorded and presented - despite the mariner log format of the entries - from memory. On one hand this is easily a matter of indifference to the reader, who if anything appreciates the 
attempt at detail, regardless of whether it is off the mark. But on the other hand, it stirs a question: why provide so much (extraneous, even) detail if doing so runs the risk of getting it wrong, only to allow for this concession later on? The sheer minuteness of detail throughout the narrative seemed to work, until now, to exhibit the "strict accuracy" Pym denies pretending to, but after Pym's admission in the footnote, it stands to reason that the more detailed a coordinate Pym presents, the more of a chance is present that the coordinate is incorrect.

It seems, then, that the narrator, not just despite but due to his caveat, is guilty of what he tries to deny: the narrator's level of detail invites us to accept said detail, in turn making the account more feasible. But the reader is also invited to not accept the detail, an invitation which would likewise function to make the account more feasible, as this admission of limitation implies a committal to restraining from runaway claims and nontruths. This simultaneous invitation and discouragement to take the novel's details as fact, taken together with the ambiguity of the metatextual phrase "the first portion of what is here written” more than renders the narrative suspect. The reader, snapped into awreness of the textuality of the novel, is forced to ask how much of the account is contained under this "first portion"? When does "the period of which this first portion treats" end and the accurate documenting begin? It is not at all clear whether this moment in the text is part of this first unreliable part or not. Just as the blank geographies of the Antarctic seas are without strict definition in the narrative, the geography of the text itself proves porous if not disoriented and ultimately map-resistant for the explorer of it - the reader - trying to navigate the space in and of the narrative. 
What the reader can detect throughout Pym is a rhythm of recurring collisions, physical and phenomenological: the physical collision between the Penguin and the Ariel; in the tomb-like hold of the Grampus, the phenomenological collision between experiential scales of space (and between the gothic and the nautical epistemologies); and in the antipodal space of terra incognita, the total destruction of cartographic and literary record. There is another type of disruption at work as well; not collisions of the physical, but the kind dealing specifically with the non-physical. Recall that The Narrative of Arthur Gordon Pym's structure has been examined and understood as four discrete episodic blocks corresponding to the vessels carrying Pym onward to the inconclusive end of the narrative, and I have suggested a spatial disruption recurring throughout the narrative. A different, complementary organizational logic can be discerned from Pym’s diagesis as well: the persistent rhythm of appearances and disappearances, apparitions and vanishings punctuating the narrative, some strange because they occur before Pym's very eyes, and some strange precisely because they do not. Objects and beings appear and disappear in the narrative without explanation. The most blatantly of course the appearance of the "shrouded human figure" that rises out of the oceanic chasm (239) and the ultimate disappearance of Pym along with the remaining final chapters. The narrative, from its recurring pulses not only of collisions and disruptions, but of phantomlike spectrality, can be read as a narrative obsessed over ruptured material space.

There is an innate uncanniness in the phenomenon of material bodies and things apparently springing into and out of existence, ghost-like, melding presence and absence in disturbing ways that, by threatening the apparent binary's very median, necessitate a reorientation of one's relationship to the world. The novel makes transparent the interplay 
between appearance and disappearance, materiality and nothingness, which in turn makes Pym's description of the duration of his trip as "the time in which I was absent" as fitting as it is eerie. Yet, it is my point here that the uncanniness of apparitional phenomena is amplified to a degree by virtue of being executed during the long voyage, the space under consideration - the yawning ocean - characterized starkly by lack and nothingness. In "The Voyage," Washington Irving writes "from the moment you lose sight of the land you have left all is vacancy” (52). For Irving, being thrust into a void-like world in which "all is vacancy" has real existential repercussions: "a wide sea voyage severs us at once [from a familiar chain of causality]. It makes us conscious of being cast loose from the secure anchorage of settled life, and sent adrift upon a doubtful world. It interposes a gulf, not merely imaginary, but real, between us and our homes - a gulf subject to tempest, and fear, and uncertainty, rendering distance palpable, and return precarious” (52-53). In other words, the gulf of the long voyage is itself uncanny. To experience it is to experience our very distance from home, our very out-of-placeness. Furthermore, as such an environment of absence and nothingness primes us for subsequent experience ("the temporary absence of worldly scenes and employments produces a state of mind particularly fitted to receive new and vivid impressions"[52]), occurrences that would be uncanny in their own right seem to be uncanny twice-over.

Ship appearances in general are a common trope of nautical fiction, but The Narrative of Arthur Gordon Pym employs ship appearances that are particularly strange and unsettling. While stranded aboard the wreckage of the Grampus, Pym spots a ship on the horizon, stoking his hopes of rescue and survival: "I suddenly discovered a sail to the eastward, and on our larboard bow. She appeared to be a large ship, and was coming 
nearly athwart us ... upon her getting nearer, I saw distinctly that she was heading immediate for us, with her light sails filled” (140). Pym, now sure the ship is coming right at them and rescue is imminent, points it out to his companions, and the three all seeing the "sure prospect of deliverance” join together in "madness," "gratitude and ecstasy” (141). However, Pym’s celebration is short lived, stopping as abruptly as the ending of the narrative: "I was suddenly called to my recollection, and once more to the extreme of human misery and despair, by perceiving the ship all at once with her stern fully presented towards us, and steering in a direction nearly opposite to that in which I had perceived her” (141). In a single moment (“all at once”) something new appears to Pym: the truth that the ship that has appeared is going in the very opposite direction, away from the Grampus. Not only is Pym unable to ascertain whence the ship could have possibly come, its materialization in medias res defies Pym's understanding of trajectory. It is yet one more moving entity without a perceivable origin, seeming to blink into existence for Pym as easily as it leaves and disappears.

Significantly, Pym’s companions are not easily persuaded of the mistake: “they replied to all my assertions with a stare and a gesture implying that they were not to be deceived by such misrepresentations” (141). Certainly, a ship appearing out of nowhere moving directly away must be some sort of misrepresentation, and the natural response for the other survivors is not to puzzle over the phantom nature of the ship but rather disbelieve Pym’s assertions about the ship’s direction: “In spite of all I could say or do to the contrary,” Pym’s close friend and fellow shipwreck survivor Augustus "persisted in saying that the ship was rapidly nearing us, and in making preparations to go on board of her. Some seaweed floating by the brig, he maintained that it was the ship's boat, and 
endeavored to throw himself upon it” (414). On the surface Augustus is going mad from being stranded on the Grampus, and the uncanny apparition of the salvation that never was only serves to expedite his madness. A deeper interrogation offers another possibility. It is easier for Augustus to believe the floatsam is a rescue boat than to believe the altogether unfamiliar phenomenon of a ship that appears and disappears just as easily. Such a shock to one's own being, as the uncanny experience is, is unthinkable; it is outside Augustus’s epistemological frame of reference. Rather than madness, and quite like Pym’s description of the perpetual day in polar geographies, Augustus is sane and cool-headed in the face of the uncanny, preferring to attend to his reason and rationality (here disbelieving the ship springing into and out of his perception) over what is available to him empirically.

Barring this example's singular strangeness, the occurrence of ships appearing and disappearing on the horizon is indeed natural for a narrative that takes place upon the ocean. Given the inherent uncanniness of appearances/disappearances, boosted by the uncanny experience of being stranded in a space of void-like expansiveness, such a natural occurrence is nevertheless highly suggestive of the strange and unhomelike, if not made more uncanny by its perceived ordinariness. In the next chapter, I more fully take up the phenomenon of spotting new sails (and return to Pym's hellish second ship appearance), as the narrative of "Benito Cereno" begins with the very moment of spying a strange ship on the horizon - an interruption in its own right. But ships are not the only things that appear and vanish; later, aboard the Jane Guy, Pym and company cross and re-cross an empty span of ocean in search of a group of islands, the Auroras. Pym explains that there have been conflicting reports regarding the existence and location of 
the three islands, and gives us a short history of the different expeditions to them (complete with coordinates) and their results. The enterprise of doubling back on oneself is already tinged by the uncanny, ${ }^{6}$ but the search for islands that seem to vanish and reappear - space wavering between empty and dense - is especially unsettling, if still natural for the imperfect art of navigation.

Appearances and vanishings less natural (although these vanishings, as natural as they seem, are never so; they are always unsettling, displacing) to the nautical environment occur, as well. Recall that Pym is surprised when his own faithful dog, Tiger, appears, smuggled into the hold of the Grampus. Later, the dog instrumental in saving Pym’s metaphysical and physical existence vanishes altogether from the narrative so completely that the reader us bit even told of the disappearance. Rather, the dog just ceases to be mentioned. To be sure, one can suppose his fate: the last time the reader sees Tiger, he is helping out, even turning the tide, in the fight that allows Pym, Augustus, and Dirk Peters to retake the Grampus during the tempest that takes the brig's mainsail, rendering the ship little more than an unstable, floating barge in the middle of the Atlantic. The surviving party must lash themselves to the deck to avoid being washed overboard by the severe waves crashing down on the weather-beaten ship. Surely Tiger was a casualty of the storm, yet it is conspicuous that Pym, in his narration, does not lament, wonder about, or even mention his old faithful friend, to whom, Pym tells us earlier, he thrice owes his life. Tiger disappears as abruptly as he appears in the text. While not disclosing Tiger’s fate, Pym does provide the reader with a reminder of Tiger

\footnotetext{
${ }^{6}$ In Freud's landmark discussion of the unheimlich, he provides an illustration of the phenomenon: "one may have lost one's way in the woods, perhaps being overtaken by fog, and, despite all one's efforts to find a marked or familiar path, one comes back again to the same spot” (Qtd. in Trigg 215).
} 
later when he imagines momentarily and in a moment of crisis that the body of Peters lashed to the deck is his old canine friend. Oddly enough, he does so without further commentary, serving merely to remind the reader that Tiger was present at earlier points of the narrative, and thus highlighting his absence without having to say anything about it; in effect, the reader glimpses a pure memory, raw and indifferent.

The vanishing that is the most natural is also the most unnatural: that of Pym's dear friend Augustus, not just in front of his eyes, but in Dirk Peters's hands. During the confinement to the floating wreck of the Grampus, Augustus expires from his wounds and malnourishment. Pym and Peters initially cannot bring themselves to submit Augustus's body to sea burial; his death is at noon, but the reader told that it is not until sometime after dark that the two bring themselves to throw the body overboard. Sitting by the corpse is a more palatable prospect than dumping it into the deep, less disturbing than enacting "the total erasure of a shipmate's material self” (Blum 175), leaving no grave or monument behind. Absence and nothingness in the wake of a once-living friend's material body is, for Pym and even the more seasoned Peters, more horrifying, more fraught with existential angst, than confronting his withered body. When Peters and Pym finally do attempt the sea burial, the body is already falling apart: "it was then loathsome beyond expression, and so far decayed that, as Peters attempted to lift it, an entire leg came off in his grasp” (163). That the body is dissolving in Peters's hands is not just disgusting, it is uncanny - a material slice of the unhomelike - as severed limbs are simultaneously recognizable and strange. The body, as it falls into pieces, is rendered unrecognizable as the material that once was a being, now a "mass of putrefaction” (163). As it slips into the water, it is fully torn apart and devoured by sharks: not only does the 
body not find a resting place, but its material is severed and strewn at the very moment of burial.

Bodily dissolution (as well as the space of absence left in the body's former space) is highly uncanny, comprising a trope that will be explored in gothic or horror texts later on, such as Oscar Wilde's The Picture of Dorian Gray and H.P. Lovecraft's "The Colour Out of Space.” The distorted and disintegrating material being is a literal embodiment of horror, and the resulting empty space is, in terms of spectacle, a nonimage, yet one that reverberates with memory; an image of absence. While Augustus's rotting flesh being viscerally torn apart by sharks is extremely spectacular, it is what is left remaining afterwards that is haunting and uncanny: not so much what remains in the empty space but of the empty space itself, a space containing no outward features but still a definite, defined space in its own right, defined by its emptiness. Our attention is directed not merely to the location once occupied by a material body, but instead to the emptiness of the vacuous space now unoccupied. Edward Casey, in the same vein of thought as Merleau-Ponty, notes that a body moving through space is always necessarily in place, even as it moves out of one it moves into another. Clearly, in the case of Augustus this is not always so. The ultimate displacement is not from one place to another, but from something into nothingness.

Augustus's rapid deterioration, decay, and disintegration is as extraordinary as the fact of ships, islands, dogs, shrouded white figures, and chapters appearing and disappearing without being announced and without a trace. Interestingly, this bodily vanishing does not incur in a memory-haunted, gothicized place (such as Dorian’s playroom or the chamber of the "Raven"). Rather the opposite: upon the rescue of Pym 
and Peters, Pym seems to forget the experience of the episode. Augustus's vanishing not only lacks a physical marker or monument, Pym cannot even plot the coordinate of his friend's final breath (nor the last place where his body vanished from) reliably on a map. Rather than a close circumscription of space or unity of place, Augustus slips into void, as did Tiger before and as will the ship, as will Pym and Peters, as will the final chapters. This is the gothic convention turned on its head, and possibly a lot more frightening: a material body that gives way to void and nothingness without even memory, to horror vacui.

Although Casey interprets the strict void a phenomenological impossibility, Poe has landed in the proximity of a poetics of the void. Pym's nautical understanding of geography is enlightenment at heart; he understands himself as moving through homogenous, geometrical space in the vein of Newton or Kant: that is, featureless space, only made meaningful by the plotting of charts and navigational, imaginary lines of latitude and longitude. Yet when such vanishings occur in these non-places, the very absence defining them is foregrounded. What is revealed in Poe's poetics of the void, of pure emptiness, is that, in the struggle between enlightenment rationality and antienlightenment experience, the absurd conclusion is that a purely rational understanding of space eventually leads to the horrifying abyss of vacuity.

Pym's conventions; formal composition; and dynamic between open and closed, immensity and the body, molecules and nothingness, embody the young republic's anxieties over geographic space, home, and the self's place in the world: namely a reverberating, simultaneous (much like Pym's radically ambivalent attitude and fantasies that catalyze his journey) excitement and dread of America's nebulous form and the 
spaces Americans found their world expanding into in the nineteenth century. This rings all the truer given that the antebellum discourses that Pym rises from are discourses that position geography and geographical literacy at the very forefront in representations of a distinctively American identity (Brückner 3). The novel, while adapting an air of mapmaking factuality throughout, contains a very odd sense of spatial causality, reinforced further by the uncanny geography and textual space in which the novel plays out. Irving writes "In travelling by land there is a continuity of scene and a connected succession of persons and incidents that carry on the story of life, and lessen the effect of absence and separation” (52). Moving through blank nautical space, on the other hand, disrupts familiar experience and displaces, highlights, or amplifies absence and separation. Pym is a story that, rather than being carried on by an unbroken chain that we can trace back "link by link" and "feel that the last still grapples us to home" (52), is structured, carried on even, by exactly such absences and separation from the homelike - a poetic expression of the nation's experience of itself and the larger world it seemed to be spilling into. Now, I turn to a work that was clearly influenced by Pym, albeit employing the mechanism of the spatial disruption in a subtler (and more havocking) way: Herman Melville’s “Benito Cereno.” 


\section{CHAPTER TWO}

"Lurking in the Hold”: Space, Place, and the Uncanny in "Benito Cereno" Herman Melville’s “Benito Cereno” (1855) is a novella that operates, I wish to argue, first and foremost through the aesthetics of the uncanny, represented most vividly by the work's primary setting and structure: the ship San Dominick and its containing waters. A lingering uncanniness hovers aboard the Spanish merchantman, reverberating in every nook and cranny from hold to forecastle, in the structure of the vessel itself from hull to balustrades up to its shrouded figurehead, and in the peculiar grey environment the weather-beaten ship is lurching and rolling in at the opening of the text. And no wonder that an anxious and unusual dread pervades the space of the vessel: originally outfitted for the colonial transport of enslaved Africans, the fictional slave ship is subject to a “piratical revolt” shortly before the beginning of the narrative (88). By the time American captain Amasa Delano spies the San Dominick off the coast of Chile, the recognizable white-master/black-slave structure onboard is inverted: the Africans are no longer part of the ship’s cargo but are in fact running the operation, holding the surviving Spaniards their prisoners. What registers as familiar - the accepted racial logic of slavery - while appearing as such on the surface, is supplanted by the unfamiliar: the inversion of that logic.

Delano, importantly, cannot see this, largely due to the play-acting stratagems of the rebels (and especially those of the mastermind of the revolt, their leader Babo), but also because the inversion of the race-based master/slave relationship is, to use the late Michel-Rolf Trouillot’s phrase, “unthinkable” for Delano. That is, such an unfamiliar inversion is outside of Delano’s epistemic framework, not even an option to the turn-of- 
the- $19^{\text {th }}$ century man's entire range of imaginative possibilities. And yet, in spite of Delano's obliviousness to the actual events, something nonetheless feels strange aboard the vessel; in fact, the ship seems "unreal" upon first boarding (39). While Delano cannot see plainly the unfamiliar, the captain cannot shake the succession of oscillating impressions that something about the San Dominick is amiss. Because the narrative's account on and of the San Dominick is focalized through (though not restricted to) Delano's experience, which is in turn shaped and determined by the captain's limited worldview, the reader is not privy to the fact of a prior rebellion either. And yet the narrative posits the San Dominick as a space in which something is strangely out of place. As with my previous chapter, my focus here is on this out-of-placeness, what I have been referring to as the aesthetics of the nautical uncanny. Drawing on the insights from phenomenology outlined in my introduction and previous chapter, I examine how the uncanny is reflected in, even manifested in, spatial features of the San Dominick and the external space that envelopes it. To be sure, the presence of the uncanny in "Benito Cereno” has been noted and commented on. Laura Barrett has explored the linguistic uncanny at work in the novella, that is, the way the uncanny "lurks in the space between the signified and the signifier" of the novella's narrative voice (405). Here I am interested in the ways the uncanny lurks in the spaces present in the novella, including the space of and within the San Dominick, the exterior geography enveloping it, the bodily spaces of the sailors and slaves aboard the ship, and a particular place not literally present but being implicated throughout: revolutionary Haiti, to the $19^{\text {th }}$ century, a site of the uncanny perhaps without equal. 
While criticism of "Benito Cereno" has generally moved away from examining the "Gothic sensationalism" found within the novella in favor of exploration of notions of race and racialism (Toal 33), in this paper I want to return to the gothic elements of "Benito Cereno" and the sensations engendered by them. This is not to neglect or diminish the racial or political atmosphere of the novella; to examine the uncanny elements of "Benito Cereno," is, in an important way, to examine the problems of race and racialism within the novella. In addition to interpreting the nautical uncanny as a poetics for American anxietal space, my reading connects the darkness and frustrated confinement aboard the San Dominick with the darkness and confining imprisonment of slavery. I do so via a somewhat (perhaps fittingly so) circuitous route, asking how the San Dominick - itself characterized by uncanny spaces of bizarre anxiety, of memoryladen hauntings, of darkness, and of restriction, and situated in a broader geography of vastness, of emptiness, of restriction amongst calm weather, and of sheer distance from home - serves as a geographically distortive link bridging the unhomelike blank continent of Antarctica with the question of slavery and abolition in antebellum America. Even more specifically, I argue that the uncanniness not so much articulated as intuited or sensed within the novella can be interpreted as a poetics for conceptualizing and communicating the "unthinkable" nature of slave revolts in general and the Haitian revolution in particular.

It is worth briefly reiterating my working understanding of the uncanny in a way that emphasizes the spatial aspect I take to be inherent in the phenomenology of its experience. The uncanny is usually conceptualized and constructed in a way privileging temporality: something is said to be uncanny when the familiar becomes unfamiliar, or 
vice versa. In this construction, the unfamiliar here does not replace or override the familiar, but exists simultaneously: the uncanny phenomenon is both familiar and unfamiliar at the same time. Thus, things that are merely mysterious or enigmatic - as they are aboard the San Dominick - are not necessarily uncanny. The go-to example is often the severed, bodiless body part. Its uncanniness derives from its being at once ordinary (here because of its intimately recognizable form) and alien (due to being divorced from its usual context). It is strangely familiar. However, simultaneity alone is not enough to explain where the uncanny experience derives its purchase and why confronting the uncanny can have ramifications of existential angst.

No less important to the uncanny is spatiality. My understanding of the uncanny is that of the unsettling - that which destabilizes one's sense of identity because it calls into question (by un-settling) one's sense of place. Dylan Trigg conceptualizes the uncanny as “a displacement from the everyday [which] places us in the middle of the familiar” (27, my emphasis). Rather than envisioning the uncanny in purely temporal terms - that is, the quality of being unfamiliar while being familiar - Trigg's reconfiguring construction places as it dis-places, highlighting the inherent spatiality of an experience that is, after all, translated from unheimlich, or the unhomelike. For our purposes then, the most compelling and direct formulation of the uncanny is from philosopher Edward Casey: the uncanny experience is the "anxiety of not feeling 'at home”” (Casey x). Any account of the uncanny grapples, either explicitly or not, with the concept of home and belonging, and as such the uncanny experience can productively be imagined as an inherently spatial and place-based experience - the place in question, of course, being home - that inarticulable property that emerges from structures of familiarity, comfort, and memory. 
Based on this understanding, the primary spatial structure in the novella, the ship the San Dominick, is uncanny several times over. Located in what is, for both Melville's readers (readers of Delano) as well as Melville's reader Delano, the far-from-home geography of the South Seas, the coordinates of the action of "Benito Cereno" call to mind distance and out-of-placeness in the most literal sense. The action of the novella takes place, the reader is told, off the coast of "a small, desert, uninhabited island towards the southern extremity of the long coast of Chili” (35). This locale is not a far cry from the Antarctic Ocean, a region still ill-explored and continuing to be mapped out in 1855 . Not a far cry indeed, for it is not unusual for maps of the southern polar region from that year (then part cartographic observation, part conjecture) to include "the southern extremity” of Chile at the margins, both for illustrative purposes of orientation, and because the southern extremity of Chile and the Drake Passage - the expanse of ocean dividing Cape Horn from the South Shetland Islands and the Antarctic Peninsula - could perhaps fruitfully be conceptualized as a sort of gateway into, if not an extension of, the Antarctic region. In the 1855 Colton map (figures 2 and 3), the southern extremity of South America projects inward from beyond the boundaries of the map and is the only non-Antarctic continental landmass present.

To be sure, the action of the novella is supposed to take place off the coast of Chile’s Santa Maria, an island farther north along the coast than the language "towards the southern extremity of the long coast of Chili” would seem to imply. There is, of course, a possibility that Melville made a mistake in placing Saint Maria farther south than it actually lies, or even that he engaged in his own bit of geographical transformation 


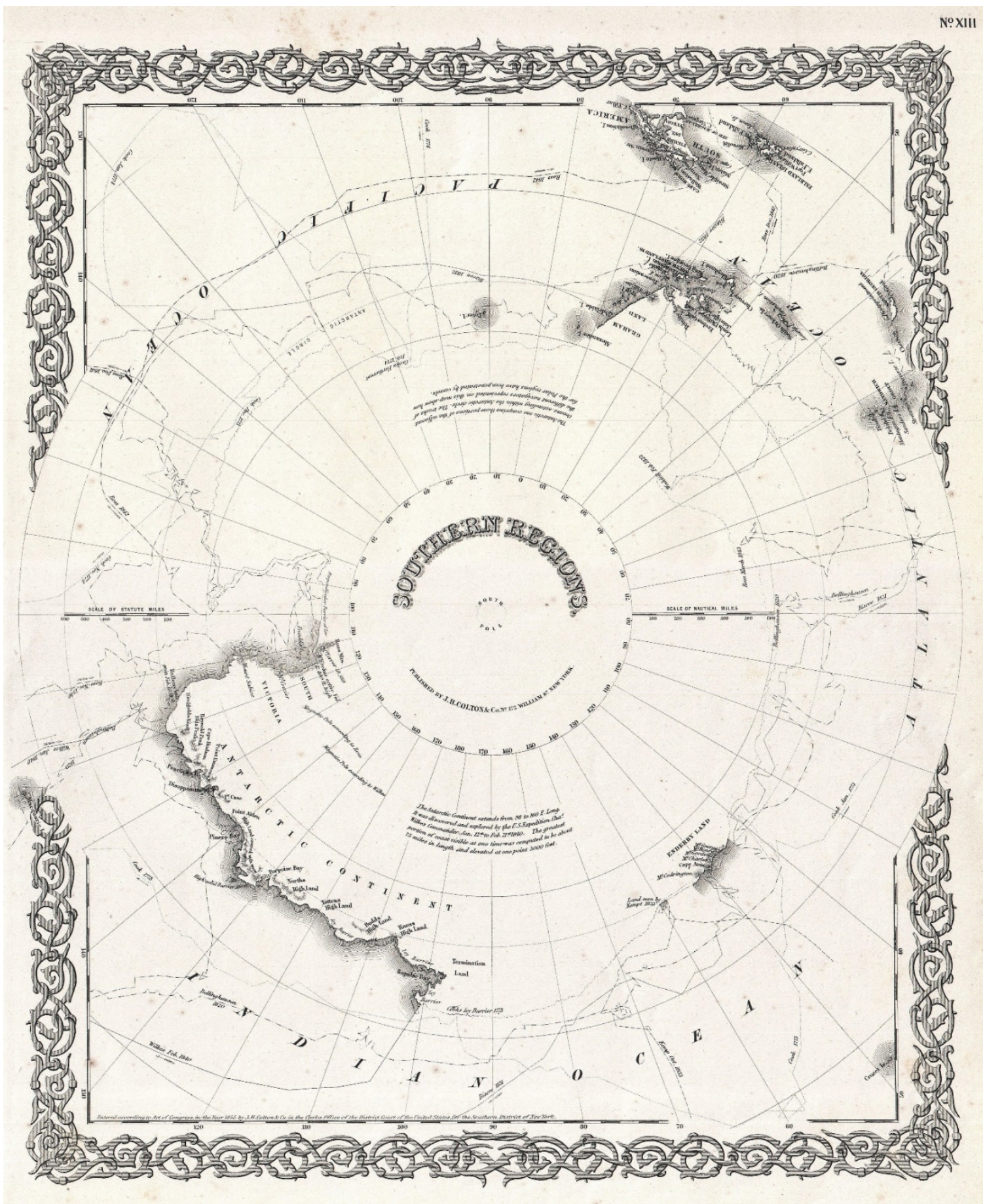

Figure 2. "Southern Regions." c. 1855 by Joseph H. Colton. Explored borders appear shaded in here due to ocean topographic lines, but the vast amount of coastline mapped is predicted sketch. The "southernmost extremity" of Chile is visible near the top right of the map. 


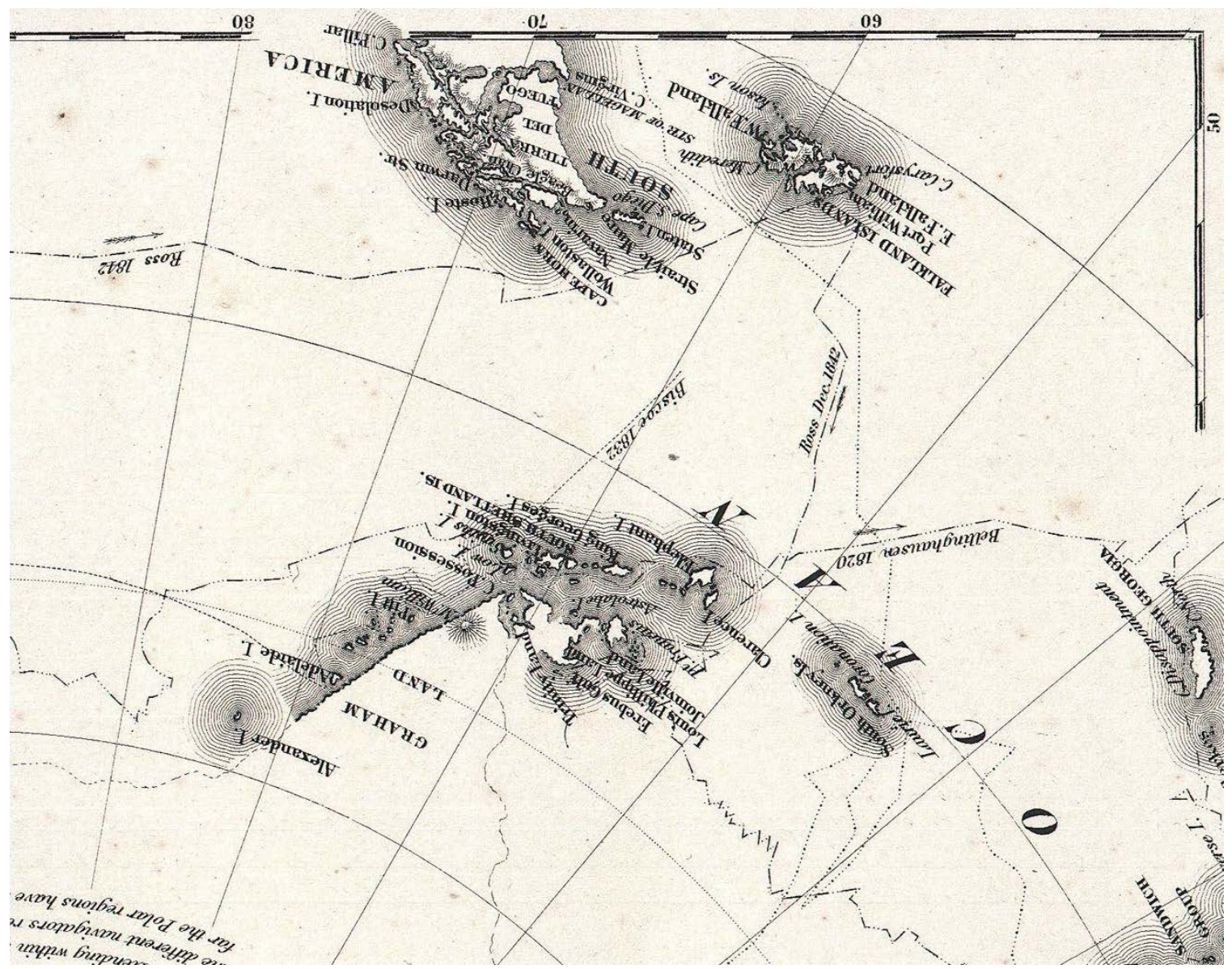

Figure 3. Detail of "Southern Regions." c. 1855 by Joseph H. Colton, $30^{\circ}-90^{\circ}$ W. Chile is located approximately at $70^{\circ} \mathrm{W}$.

so that the setting of the novella still remains an extreme space while embodying traces of New World colonialism immortalized in the island's name (echoing, of course, the ship Christopher Columbus sailed). Regardless, the extreme space is more than implied: upon first boarding the San Dominick Delano is told by an outcry of voices that the ship's troubles started soon before rounding Cape Horn. Cape Horn, at the southern extremity of South America, and thus at the southern extremity of the New World, serves not only as a navigational and symbolic marker of the feat of transoceanic movement (and of 
modernity and technology by extension), but it also is the significant middle point for the alleged tragedies on board and transformation of the San Dominick. Once a celebrated machine of nautical mastery and transoceanic achievement as attested by both Don Benito's proud demeanor and Delano’s phantasmagoric visions of Spain he has aboard the ship, apparently the passage through this extreme space has rendered the ship more or less in ruins, an artifact of the past more than a machine ushering in the future. Delano is told that before rounding Cape Horn yellow fever broke out on the ship; while rounding Cape Horn heavy gales batter the ill-manned ship and already decimated crew; and after rounding Cape Horn, the ship experienced freak calms. Reaching and crossing over the highly symbolic southern point only exacerbates the problems of the San Dominick, following which "for days together, [the vessel] had lain tranced without wind" (39). All this is to sa, that although the action of the novella does not occur at this "extremity" represented in the maps above, the site has a very real and spatial presence in the novella, manifested in the structural and corporeal damage of the Spanish ship and its diseased bodies as well as the felt absence of those lost (to Delano's knowledge) overboard or through sickness.

This gestured, if not actual, setting is at odds with the homelike in a number of ways. Most immediately is the fact of the sheer geographic distance from the zone and the origins of the characters Delano, Cereno, and Babo. Their stories intersect far from their respective homes in a way that calls attention to each character as a being-in-theworld, moreover, beings lost in the world; each character's out-of-placeness is emphasized by the distance and duration of the long trip. Interestingly for the far-flung setting, this novella is not a work of travel in the usual sense. It is not a text narrating the 
event of exploration, journey, or adventure. Rather than showcasing long traverses, the action of the text mostly takes place in a very restricted locale. The narrative, starting not with port departure but instead already asea, offers less of a fully realized picture of beings in motion than it does a sort of picture of people already thrust into a world in motion, not all that different from Henry James’s Americans abroad later.

But this particular far-from-home zone contributes to the novella’s uncanniness in ways more specific than just being far from the characters' (as well as Melville’s and his readers') homes, although as stated above the distance certainly amplifies the effect; for the action of the novella is not just far from home, but an entire world away - at ends of the earth, as it were. Strikingly, Antarctica is the single continent that nobody on Earth calls home. This only partly delineated terra nullius is nobody's homeland; it is in fact a homeless region. Not only does this landform lack any semblance of the homelike, it actually resists endeavors to familiarize the space (even while its very blankness and ahomeness invites such endeavors). The latitudinal idiosyncrasies of an area so close to a pole present a challenge for mapping (that is, for reproducing the space in an imaginative two-dimensional representation meant to be read, thereby setting the unknown in order and familiarizing the unfamiliar) insofar as the very area pushes against certain expected cartographic practices, demanding alternatives. Interesting in the two figures of the Colton map above is the way that all the text on the map orients the South Pole as a sort of up or top, something most evident when considering the detail presented in figure 2 apart from the context of the entire map. All text appearing on the map revolves around the South Pole, the tops of the letters pointing unwaveringly due south. On one hand, there seems to be nothing odd or unsettling about the azimuthal projection as it clearly 
offers the most utility for conceptualizing the geography and applying the man-made construct of lines of longitude. Yet, it is telling that a coherent map of this extremely south region must be mapped thusly. ${ }^{7}$ For on the other hand, there is something to be said about a region whose conditions necessitate alternative mapping practices. The nebulousness, the out-of-place homelessness, and the unfamiliar demands of representation of such a space are all components that lend Antarctica and its surrounding waters an air nothing short of the uncanny, a fitting setting for what I argue is an uncanny novella. Furthermore, set in 1799, a year in which the continent was not yet discovered and still a conceptual Terra Australis, and like so many other aspects of the narrative the setting itself flirts with the unknown, here physically verging on it.

This very blankness and indefinition of the area work together to produce Antarctica as a geographic space that impressed itself on the imaginations of $19^{\text {th }}$ century readers. A hot topic at the time, only fifteen years prior to the publication of "Benito Cereno,” Charles Wilkes and the United States Exploring Expedition “discovered” the Antarctic continent, the existence of which had since antiquity been hypothesized. Additionally, an expedition to East Antarctica commenced in 1853, just two years prior to Melville's work. Tellingly too, the year of the novella's publication is the same year that American explorer and antebellum celebrity Elisha Kent Kane - known for his arctic heroics as well as (interestingly enough for a discussion of the uncanny and strangeness) his purported love affair and later marriage with the notorious séance medium Margaret

\footnotetext{
${ }^{7}$ More typical projections that are useful for navigation elsewhere, such as one's based off of Mercator's 1569 map, are more than ill-suited for mapping the region. Mercator's map was one of many that posited a vast terra australis at the bottom of the world, but even maps today based on the Mercator Projection that include Antarctica necessarily distort the continent practically into nonsense.
} 
Fox - returned from leading the ice-bound Second Grinnell Expedition on the other side of the globe (see Kane's own The United States Grinnell Expedition in Search of Sir John Franklin). ${ }^{8}$ As articulated by Conrad's Marlow about a half century later, such "blank" geographies, and evidently those who would brave them, captivated the imaginations of audiences back home.

Yet, in the case of Antarctica and other distant blank spaces in the Southern Hemisphere (and South Seas in particular), not just the blankness and sheer distance were captivating; as discussed in the previous chapter, there too exists a tradition stretching back to early modernity in which antipodal space is more than ripe for utopian imaginings. This antipodes, however, is not ever allowed the status of utopian space, as the narrative begins with the space's very disruption by the appearance of the San Dominick. Other than the most elementary geographic details (namely, that the action is set "in the harbour of St. Maria -- a small, desert, uninhabited island towards the southern extremity of the long coast of Chili” [35]) the site is not allowed to be defined until Delano has recourse through, to borrow from phenomenology, the intentional object of the San Dominick.

When the ship breaks into the scene, it comes oddly packaged with something like an irruption of shimmering light: light streams from the cabin "equivocally” through the vapors rising off the bay, just as the sun pierces the hazy horizon like a "sinister eye" (36). The strange object is cause enough for Delano's reflection (from which he eventually "surmise[es] at last that it might be a ship in distress" [37]), but it is significant that the narrative representation of what Delano views from his glass is not extractable

\footnotetext{
${ }^{8}$ For Kane’s status as American celebrity, see Sawin’s Raising Kane. For relationship with Fox, see Chapin's Exploring Other Worlds.
} 
from the spectacle of the interrupted environment as a whole. The entity, even as it interrupts the scene, becomes part of it.

Even barring ship appearances of the sort I discussed in the previous chapter, such an interruption of an environment is not unprecedented. Leo Marx pointed out a recurring trope in American literature: that of the natural scene being interrupted by the modern, the unnatural, the technological. Marx observes that time and again in American letters, as say in Hawthorne's sketches or Thoreau's Walden, the interjection and interposition of modern realities jar and destabilize pastoral idealism in the form of meditations on, in, and of wild, natural, and isolated locales. The bay in which Delano's Bachelor's Delight is moored at the start of the novella is characterized by its naturalness and isolation (it is "a spot” marked by "loneliness and lawlessness") and as such is entirely in accord with the utopic fantasy of the pastoral pre-interruption (as well as Leslie Fiedler's take on American utopia as flight from heterosexual love and domesticity, all the more emphasized by Delano’s ship’s name). Here, however, the familiar machine-in-thegarden trope as described by Marx is flipped on its head by the fact that the narrative starts with the interruption and only after describes the enveloping environment in terms of subjective experience. This is to say, the narrative opens with the interruption of a "strange sail . . coming into the bay" (35) and then backpedals to a description of that bay and the aforementioned shimmering interplay of light and vapor. Only once interrupted can the narrative turn to this locale and allow contemplation of its scene.

This is not to say that the San Dominick's appearance is not an interruption. Indeed, it is unannounced and jarring (quite literally jarring Delano out of the comfort of his berth), and although described in the gothic language of ancient ruins, the ship is a 
powerful symbol and machine of modern realities: of navigational achievements, of colonial networks, but namely of slavery. Yet far from the language of idealizing nature as well as the spontaneity of a Marxian interruption, what is to come is foreshadowed, already present in the form of shadows:

The morning was one peculiar to that coast. Everything was mute and calm; everything grey. The sea, though undulated into long roods of swells, seemed fixed, and was sleeked at the surface like waved lead that has cooled and set in the smelter's mould. The sky seemed a grey mantle. Flights of troubled grey fowl, kith and kin with flights of troubled grey vapours among which they were mixed, skimmed low and fitfully over the waters, as swallows over meadows before storms. Shadows present, foreshadowing deeper shadows to come. (35-36)

Rather than the language of natural ideal, the seascape of the space in which the Bachelor's Delight is moored at the start of the novella is troubled; not utopic nor the sort of blank space meant to be filled in or conquered, but rather occupied by shadows and marked by the language of impenetrable obscurity. When the San Dominick interrupts into the picture, the ship’s appearance, viewed through Delano's looking glass, is likewise marked by obscurity. Delano cannot read the ship. Not only does it show no colors, but even the movement of the ship is categorized by "apparent uncertainty" and thus indicates little: "[e]re long it seemed hard to decide whether she meant to come in or no, what she wanted, or what she was about” (36-37). A strange entrance of a strange ship into a likewise strange geography -- Melville’s opening narration captures an uncanny aesthetic through space and movement that sets the scheme for the narrative to come.

As touched on in the previous chapter, the effect is amplified when one considers that there is something uncanny about accounts of ship appearances in general, due in no 
small part to the inherent uncanniness of the phenomenon of things blinking into and out of existence, apparition-like, rendering the dichotomy of presence and absence permeable. Of course, as seamen and readers well know, ships do not actually materialize out of thin air, but the experience of spotting sails (and one can still productively think of such a moment as an interruption) is still very much akin to witnessing a spectral manifestation from nothingness, from space imagined as empty, due to the very long spans of time spent surrounded on all sides by expanses of featureless ocean, an “emptiness of an environment [once] presumed to be full of interest” (Blum 117). Amidst fluid, seemingly unlimited, homogenous space, the appearance of new sails on the horizon interrupts the emptiness and cannot fail to be surprising, as it always must seem like the appearance of the ship is an appearance from and against the background of nothingness, from emptiness, an appearance out of nowhere, as it were.

It will be illuminating to our consideration of strange sails to return to The Narrative of Arthur Gordon Pym here, in which the uncanniness of the trope of the ship appearance reaches its extreme. While Pym and his fellow survivors are trapped aboard the wreck of the Grampus, ships appear on the horizon twice. One ship appears to the joy and ecstasy of those hoping for rescue, but is discovered to be going the wrong way, away from the wreck, making it seem as if it sprang into existence out of thin air. Another ship appears, this one steering in the right direction, its crew appearing to be waving and smiling at Pym and company as it draws closer. Compare its erratic steering to that of the San Dominick:

The awkward manner in which she steered, too, was remarked by all of us, even excited as we were. She yawed about so considerably, that once or twice we thought it impossible she could see us, or imagined that, having 
seen us, and discovered no person on board, she was about to tack and make off in another direction. Upon each of these occasions we screamed and shouted at the top of our voices, when the stranger would appear to change for a moment her intention, and again hold on towards us this singular conduct being repeated two or three times, so that at last we could think of no other manner of accounting for it than by supposing the helmsman to be in liquor. (Poe 139)

The jerking, strange interruption of the ship bears comparison to Melville's text. In both cases, when the homogeneity of the space is interrupted thusly, the new occupant provides a feature to the otherwise and thitherto featureless space. Importantly (and this goes with any appearance sighted from the masthead: whales, rocks, land), this new entity must be read, as we have seen with Delano’s sizing up the San Dominick. The sole other object in the objectless blank space becomes the intentional object, the entity to which the lookout is bent on deciphering. In The View From the Masthead: Maritime Imagination and Antebellum American Sea Narratives, Hester Blum demonstrates how the novice transforms into the seasoned seaman - the old salt - precisely at the locus of this literacy, yet Delano’s reading of the appearing ship (as is his reading of the texts around him throughout the narrative) is vexed, to the point that Faye Halpern, in exploring the pedagogical problem of teaching students to recognize and read complexity, argues that Delano "resembles the first-year reader, with his almost physical aversion to digging deeper in his readings of the 'texts' surrounding him” (557).

Pym's closer observation of and then contact with the vessel can also be compared to "Benito Cereno" in that the flitting mirage-like image seems to change and metamorphose upon nearing, and in the physical aversion consequent to such a reading. In Melville’s text, the San Dominick is described “[u]pon gaining a less remote view” as a floating "white-washed monastery after a thunderstorm” (37). Then, “[u]pon a still 
nigher approach, this appearance was modified, and the true character of the vessel was plain” (37). Spatial proximity can alter the intentional object's impression, and the implication here is that discerning reality entails physical movement in relation to the object of intention. And yet, this realer, truer epistemic involvement with an uncanny object of intention by no means necessarily leads to more lucidity or transparency upon closer inspection. When Delano boards, the "true character" of the merchantman shifts again, now to that of a "strange house" in which all is confusion:

Always upon first boarding a large and populous ship at sea, especially a foreign one, with a nondescript crew such as Lascars or Manilla men, the impression varies in a peculiar way from that produced by first entering a strange house with strange inmates in a strange land. Both house and ship, the one by its walls and blinds, the other by its high bulwarks like ramparts, hoard from view their interiors till the last moment; but in the case of the ship there is this addition: that the living spectacle it contains, upon its sudden and complete disclosure, has, in contrast with the blank ocean which zones it, something of the effect of enchantment. The ship seems unreal; these strange costumes, gestures, and faces, but a shadowy tableau just emerged from the deep, which directly must receive back what it gave. (39)

Striking spatial forms are invoked here in order to express the strangeness of boarding ships in general and ships from distant places in particular. The uncanny object (here an uncanny space) is all the more uncanny by its contemplation. The self-same close inspection that breaks through the obfuscating "ramparts" only serves to expose the interior in all its enchanting strangeness. The alterity within is contrasted with the blank monotony which "zones” the space, in turn working to reaffirm the space’s very alterity. The blankness without, as mundane as it is, is also strange and unsettling insofar as it sets the stage for the uncanny by its compression and homogenizing of geography. Amidst the bustle of the interior, too, bodies of Others are "nondescript," negated, blank. Thus, as the 
strangeness bleeds outward into the empty space, a blankness pervades inside as well as out. In this example, any concept of an inside/outside distinction finds itself imploded. The uncanny object is a paradox of alterity and mundane nothingness, much like the severed limb is both familiar and not.

Pym, too, experiences the spatially-determined transmutation of his object of intention. As the incoming ship draws closer to the Grampus, it proves to be a "triple horror”; as it gets directly alongside of the Grampus, Pym sees that all aboard the ship are dead and "in the last and most loathsome state of putrefaction" (140), the waving, smiling seaman a corpse lashed to the railing, being torn apart by a blood-stained seagull. The sheer horrifying spectacle is horror number one; the "grievous disappointment" that the ship is not the salvation it appeared to be is horror two ("we could not help shouting to the dead for help! Yes, long and loudly did we beg, in the agony of the moment, that those silent and disgusting images would stay for us, would not abandon us to become like them, would receive us among their goodly company!” [140-141]). Lastly, horror three is not so much the piece of rotting human flesh dropped on the deck of the Grampus from the bird's beak as it is the knowing glance the nearly starved seaman share with one another, a moment of “a degree of intense and eager meaning” (142). Contact with the uncanny here is simultaneously contact with that which was not only "unperceived" (that the ship’s crew were corpses, one of which was animated by the exertions of a carnivorous bird) but that which is "unperceivable": the threat and nevertheless appeal of cannibalism. It is a moment of experiencing something alien to the epistemological framework of Pym and company. The reaction is horror - a "triple horror" - and in Pym’s moment of clarity, his "being brought to his senses,” he snatches up the "frightful 
thing” and does with it what seaman do with their dead: make it disappear overboard into the depths of the sea. The reaction to cannibalism is to make it disappear, not to entertain it. And yet, as happens with the uncanny, this experience sustains - the crew actually gives in to cannibalism shortly after, albeit a highly-structured cannibalism organized by the drawing of lots. This paradox of rationality and savagery is the continuation of the uncanny experience had with the corpse ship.

The horror of Pym's episode is one of many instances in that text of the gothic transported to the ocean. Likewise, as Delano makes contact with the San Dominick and once aboard the ship, the structural features of the vessel - "ancient" and "left to decay" make heavy use of tropes of the gothic mode. In rallying himself against the dread he feels on board the ship, Delano asks himself whether it is in his destiny to "be murdered here at the ends of the earth, on board a haunted pirate-ship by a horrible Spaniard?” (66) Largely in jest in order to ridicule his own misgivings, this question nonetheless demonstrates the intersection here between seafaring, distant far-from-home geographies, and gothic hauntings. And to be sure, the space of the San Dominick is haunted:

As his foot pressed the half-damp, half-dry sea-mosses matting the place, and a chance phantom cat's-paw - an islet of breeze, unheralded, unfollowed - as this ghostly cat's-paw came fanning his cheek, his glance fell upon the row of small, round dead-lights, all closed like coppered eyes of the coffined, and the state-cabin door, once connecting with the gallery, even as the dead-lights had once looked out upon it, but now caulked fast like a sarcophagus lid, to a purple-black, tarred-over panel, threshold, and post; and he bethought him of the time, when that state-cabin and this state-balcony had heard the voices of the Spanish king's officers, and the forms of the Lima viceroy's daughters had perhaps leaned where he stoodas these and other images flitted through his mind, as the cat's-paw through the calm, gradually he felt rising a dreamy inquietude, like that of one who alone on the prairie feels unrest from the repose of the noon. (63) 
The passage above deserves quoting at length. The narrative presents a memory-laden place - a place in which, through its ruinous aspect, the past still resonates - while also appealing subtly to the senses (the phantom, ghostly caress of wind fanning Delano's cheek). Memories can be triggered by such sense stimuli, but also the passage makes the ghostly presence of the past not just imagined but felt. The ship is haunted by memory: the legacy of Spanish empire but also, unsaid in this passage but implied in the narrative as a whole, the legacy of slavery, the abolition of which was a pressing topic in the United States in the year of the novella's publication.

Perhaps the most iconic gothic moment in "Benito Cereno" is the big reveal of the San Dominick's grisly figurehead: the prepared skeletal remains of its (and the mutinous slaves') former owner, Don Alexandro Aranda. When the reader, limited as we are through the prism of the narrator, first hears of Don Alexandro's death, the consternation of Benito Cereno is apparently the frustration and tragedy of the captain not retaining his friend's body - the uncanny “total erasure of a shipmate’s material self” (Blum 175). The frustration stems from, so the reader thinks, the inability for Benito to memorialize his friend through the interment of his corpse. And yet, in the literal reveal as the canvas comes off the San Dominick's prow and the body is exhumed, as it were, the reader learns that Cereno's vexation derives from more than just the inability to memorialize his friend: the fact that his friend has been memorialized in another way. In a surprising twist, Don Alexandro's remains are repurposed not to remember and to extol Aranda's life, but to condemn, warn against, and set an example of the slave owner. It is not Aranda's life being monumentalized, but the very fact of his murder. The experience of a corpse repurposed (indeed, purposed to other ends at all) is tinged with the uncanny. Don 
Benito's horror over his friend's death is not due to the absence of his body, but because that body has been transformed into a monument symbolizing the realities of the inverted power structure aboard the ship - in effect, a monument to the unspeakable, unthinkable, uncanny.

Gothic space, like the labyrinthine mazes of the San Dominick's interior, is often that of coffin-like enclosure, but in "Benito Cereno" the gothic interposes itself onto the wider space of the ship in surprising ways. The fact that the San Dominick is a vessel that, contrary to its design of traversing fluid geographies from "one colonial port to another” (37), is bizarrely amidst freak "calms of unusual duration” (76) renders the ship as little more than a floating barge, echoing of course the wreck of Pym's Grampus. While "to be becalmed for two months" is "at least, unusual” (75) - perhaps too unusual; the provided portion of Don Benito's deposition is ambiguous and only indicates, for certain, five days of calms - the reader is told that being confined to the static space of a ship in calms tends to have a "morbid effect on the mind" (67). Although calms are, after all, natural and even expected maritime phenomena, a reality that sailors of the time could expect to experience on occasion, one must consider the oddity of non-movement on the sea. Even when actively sailing, sea-life is characterized by an emptiness and monotony that compresses vast geographies, rendering oceanic space homogenous. Blum demonstrates that the next step logical to dealing with the boundless monotony of space at sea is to turn one's attention inward, both to the physical maritime labor of maintaining the ship as well as to the mental, intellectual labor of contemplation, thought, and imagination. This is to say that the sailor responds to spatial realities that cause a feeling of dislocation by focusing his attention elsewhere - labor, whether physical, intellectual, 
or operational - becomes the object of intention; the sailor's consciousness is bent towards this end and thusly has some orientation in an environment otherwise lacking in it. In the case if calms (as here), however, the sense of dislocation must be amplified by the fact that, rather than traversing homogenous space, the seaman is fixed, contained, confined amidst open air. Such stasis on the open seas transforms the machine of navigating vast geographies into something more like a prison, nullifying the movement that, in many ways, makes a ship a ship, instead fixing that ship to a particular geography.

As demonstrated in the previous chapter, this interplay of spatial restriction upon otherwise fluid geography (in Pym caused by storm damage, here due to the surprisingly deleterious effects of calm weather) strikes an uncanny chord in its melding of strange and familiar, gothicized enclosure and seafaring boundlessness. The open-air space of restriction and confinement that delineates an important portion of The Narrative of Arthur Gordon Pym is the same space in which Pym watches his few surviving shipmates slowly flirt with madness; partakes in a structured, lot-drawn cannibalism; and watches his dead friend get lifted up only to have the rotten body decompose and separate instantly, among other identity-havocking experiences. The amplification of the openclosed confining nautical space's effect is all the more apparent when one considers that the static ship - whether wrecked, becalmed, or trapped in by ice - has precedence as the location of uncanny encounters, experiences, and stories. Before Pym, Mary Shelley’s Frankenstein's frame narrative takes place on Captain Walton's ship in the arctic sea, enclosed on all sides by sheets of ice, unable to move. It is in this open-close frozen seascape that Walden observes another giant white figure through the polar mists: Frankenstein's monster, almost an emblem of the uncanny in his animated, variegated, 
cadaverous appearance. Both Frankenstein and Pym intermingle claustrophobic space with the sea voyage. Benito Cereno partakes in the tradition of this nautical uncanny, the mingling of familiar and unfamiliar spatial phenomena with the long voyage in a manner that amplifies the already uncanny sense of enclosure.

Commentators on the American gothic have shown how the tradition can productively be understood in terms of American obsessive anxieties about the nation's historical crimes (Savoy 168). In the American context, the “dark recesses of [America’s] own history” that continue to haunt are, in large part, memories of racialized violence: namely, the colonial liquidation of American Indians (Savoy 187) Yet, it is not merely the guilt of past sins that haunt antebellum American readers and writers; the gothic, is a mode well-suited for responding to the current pressing issues of the day. Polar exploration was not the only pressing issue in the United States in the year "Benito Cereno" was published; the most current and pressing of all was the question of the abolition of slavery (Savoy 181).

In 1799, the year "Benito Cereno" is set, the abolition of slavery - in fact, fullfledged revolution - was in the works on an island nation sharing the San Dominick's namesake and located on roughly (allowing the coordinates of Cape Horn) the same line of longitude as the action of the novella and the Antarctic locales gesture towards. Jonathon Beecher has convincingly demonstrated that a source for Benito Cereno is in fact the Haitian revolution and that Melville was interested in and "pondered deeply some of the problems that Toussaint [Louverture]'s life presents” (45). The subtle Babo takes on physical and psychological characteristics of Toussaint Louverture; his small stature as well as his performance echoing the methodical restraint of Toussaint. If so, then it 
makes sense that "Benito Cereno" can be thought of as a novella that turns on gothic conventions, albeit surprisingly employed, as in the literature of the $19^{\text {th }}$ century Haiti becomes an important site of the gothic. Lizabeth Paravisini-Gerbert argues that not only was the Caribbean "the premiere site of the colonial and postcolonial gothic since the early nineteenth century” (233), the Caribbean is “a space that learned to 'read' itself in literature through Gothic fiction” (233). Literary consumption and production in the Caribbean modeled itself after European fiction that imagined the Caribbean as a site of the uncanny. The reading that must obtain throughout "Benito Cereno" - from the moment of beholding the strange ship through the mist and shadows, to Delano's vexed reading aboard, to the reading of the deposition in Peru - is fairly consistently the reading of gothicized texts (the ship as a floating monastery, the labyrinthine interior, the horror of slaughter). Likewise, Babo and the rebels re-produce the text Delano would write, right down to "naked nature," even in a somewhat playful self-parodying nature, as evidenced by Babo’s performance of shaving Don Benito. The hatchet-polishers and the Ashantee oakum pickers are deliberately put in place, too, as "gothic literature - whether written in Britain or the Caribbean - in its attempt to address the violence of colonial conditions, has focused on this region's African-derived belief systems ... as symbolic of the islands' threatening realities" (234). "Benito Cereno" uses gothic and uncanny elements in reimagining the events of the Haitian revolution, the uncanny a mode for representing the "unthinkability” of the event.

Crucially, and certainly to Trouillot's point about the persistence of silence long after the unthinkable non-event, the uncanniness does not end when the San Dominick is 
retaken and brought in to harbor. Dylan Trigg writes of the consequences of experiencing the uncanny:

Often, we fail to recognize the power of the uncanny, its workings registered only belatedly and in parched fragments. At that time, we turn to ourselves in order to ask the following question: What just happened to $m e$ ? A feeling of disempowerment occurs. The unity of self-identity becomes vulnerable. No longer do we feel at ease within ourselves. The uncanny leaves us in a state of disquiet, unnerved precisely because we lack the conceptual scheme to put the uncanny in its rightful "place” (28, original emphasis).

Far from the logic and relief of "home-sweet-home,” the uncanny persists upon touching land. Don Benito’s own identity has been under assault to the very point that he cannot look Babo in the face, nor even be made to talk about certain details of his uncanny experience, such as donning a costume complete with a spectral sword, not an actual weapon but "the ghost of one" (107). The damage of the uncanny experience cannot be undone, jeopardizing still Cereno’s identity.

For Casey, in discussing the Freudian and Heideggerian senses of the experience of the uncanny and placelessness, human life is characterized by a series of separations from homeness. While Casey has place-based separations in mind, it is important to understand that, for Casey, “place” need not align spatially with a real or physical site. Place, above all, is the phenomenon engendered by a space, but need not fit the coordinates perfectly. In fact, an experience of place can be had independent of physically being located or situated in a physical locale. Don Benito experiences a departure from a familiar narrative; the revolution by black slaves causes a type of “place-panic” (ix), an unsettling sensation of being out of place. That Don Benito's placepanic occurs upon his own ship, that "strange house," and thus within a familiar space- 
turned-unfamiliar makes the experience all the more uncanny, as the unfamiliar has been interposed on and interacts with the familiar, the strange anxieties of unhomeliness pervading the home that Benito Cereno thitherto fancied himself master of. Casey writes that the natural response to the threat of place-panic is the "need to return" (x), done historically by denying the threat of absolute placelessness, or "voiding the void" (x). Delano recognizes while dismissing the strangeness aboard the San Dominick; in order to avoid becoming disoriented, he reorients himself towards order by reimagining the established order he finds familiar, such as the "slumbering negress" (62) that represents to him "naked nature” (63). A nagging feeling of out-of-placeness lurks in Delano's mind, but his response is to try and return from the atopos (Greek word meaning strange, but literally “no place”).

When the Haitian revolution occurred, according to Trouillot, observers likewise had to respond by fitting the occurrence into the narratives they knew and found familiar. This was not due to a political agenda as much as to the very fact that contemporaries of the Haitian revolution actually did not have the framework available to imagine such an event. The Haitian revolution to the $19^{\text {th }}$ century epistemology was out of place, and as such was responded to by either being dismissed entirely (voiding the void) or chocked up to other, more familiar causes, such as external meddling or miscalculation. Similarly, in Delano's more insightful moments (those verging on glimpsing the truth of the unfamiliar, moments which he strives to return from) in which he feels (not knows) that something is amiss, whatever it is that is out of place is anything but revolution from the bottom up: 
Was it from foreseeing some possible interference like this, that Don Benito had, beforehand, given such a bad character of his sailors, while praising the Negroes; though, indeed, the former seemed as docile as the latter the contrary? The whites, too, by nature, were the shrewder race. A man with some evil design, would not he be likely to speak well of that stupidity which was blind to his depravity, and malign that intelligence from which it might not be hidden? Not unlikely, perhaps. But if the whites had dark secrets concerning Don Benito, could then Don Benito be any way in complicity with the blacks? But they were too stupid. Besides, who ever heard of a white so far a renegade as to apostatize from his very species almost, by leaguing in against it with Negroes? (65)

Delano imagines a range of alternative explanations to what he observes based on his nagging, anxious feelings, tellingly negating ones that come closer to the truth while falling short of even that mark; this broadly summarizes the unthinkability of Haitian revolt and independence.

Such unthinkability is, it must be presumed, exceedingly difficult to articulate. Yet, through the feelings and sensations engendered by the spatial uncanny - the text's far-from-home atopic geography, bizarre stasis-amidst-movement, and gothicized interior of the San Dominick - "Benito Cereno" is an exploration of $19^{\text {th }}$ century notions of racism, slavery, and the (im)possibility of the Haitian revolution. By gothicizing the nautical space - a space without a home but nevertheless most "at home” when enjoying the familiar logic of fluidity, vastness, and movement - Melville's text presents a poetics of dealing with the often gothicized island nation, itself seemingly adrift in the Caribbean. If the San Dominick seems out of place to Delano and readers of Delano, it is probably because Haiti itself was (and perhaps still is) out of place in the $19^{\text {th }}$ century and to the narrative framework that resisted incorporating the uncanny island.

In the uncanny nautical space of Poe and Melville’s fictions, one sees reflected the dread of the unhomelike at the nation's very threshold. In Pym the uncanny site is not 
one site at all, but movement through various unhomelike strata. The ever-changing borders and nebulous form of the nation itself means the nation may be on the very verge of fragmentation. In "Benito Cereno," this movement is stalled, confined in a surprising retelling of the captivity narrative, albeit one that imaginatively draws in the uncanniness of terra incognita close to American shores, to the island nation that is as largely overlooked and negated as the blank geography of Antarctica. A broad conclusion here is that space can be an epistemological tool for thinking about conditions that tend to resist being embodied in other signs. As the movement through space in Pym captures a poetics of homelessness in the world - how does one talk about such homelessness, for speaking of it is contingent on being able to articulate what home is in the first place - the uncanny stasis in "Benito Cereno" implies that that very homelessness paradoxically reaches back towards home, that even when one is home, the uncanny is lurking just beyond, threatening to render home into "a strange house with strange inmates in a strange land" (39). 


\section{BIBLIOGRAPHY}

Allen, Hervey. Israfel, The Life and Times of Edgar Allan Poe. New York: Doran, 1927. 2: 846-847. Web.

Baker, Anne. Heartless Immensity: Literature, Culture, and Geography in Antebellum America. Ann Arbor: U of Michigan, 2006. Print.

Barrett, Laura. “'Light and Baffling': Uncanny Punning In Melville's 'Benito Cereno.'” Papers on Language \& Literature 47.4 (2011): 404-429. Academic Search Complete. Web. 9 Mar. 2015.

Barth, John. “'Still Farther South’: Some Notes on Poe's Pym.” Poe's Pym: Critical Explorations. Ed. Richard Kopley. Durham: Duke UP, 1992. 217-30. Print

Beecher, Jonathan. "Echoes of Toussaint Louverture and the Haitian Revolution in Melville’s 'Benito Cereno.'” Leviathan: A Journal of Melville Studies 9.2 (2007): 43-58. Web. 20 Apr. 2015.

Bezanson, Walter. “The Troubled Seep of Arthur Gordon Pym.” Essays in Literary History Presented to J. Milton French. Ed. Rudolf Kirk and C.F. Main. New Brunswick, NJ: Rutgers UP, 1960. 149-75. Print.

Blum, Hester. The View from the Masthead: Maritime Imagination and Antebellum American Sea Narratives. Chapel Hill: U of North Carolina, 2008. Print.

Brown, Charles B. Wieland, or the Transformation. Lanham: Start LLC, 2012. Print.

Bruce, Susan. Introduction. Three Early Modern Utopias. Oxford: Oxford UP, 1999. ixxlii. Print.

Brückner, Martin, and Hsuan L. Hsu. American Literary Geographies: Spatial Practice and Cultural Production, 1500-1900. Newark: U of Delaware, 2007. Print.

Brückner, Martin. The Geographic Revolution in Early America: Maps, Literacy, and National Identity. Chapel Hill: U of North Carolina, 2006. Print.

Casey, Edward S. Getting Back into Place: Toward a Renewed Understanding of the Place-world. Bloomington: Indiana UP, 2009. Print.

Chapin, David. Exploring Other Worlds: Margaret Fox, Elisha Kent Kane, and the Antebellum Culture of Curiosity. Amherst: University of Massachusetts, 2004. Print.

Colton, Joseph H. "Southern Regions.” Colton's Atlas of the World, Illustrating Physical And Political Geography. C. 1855. Wikimedia Commons. Web. 29 Apr. 2015.

Cooper, James F. The Sea Lions. Ed. Warren S. Walker. Lincoln: U of Nebraska, 1965. Print.

---. The Last of the Mohicans. Ed. Stephen Railton. New York: Barnes \& Noble Classics, 2004. Print. 
Dana, Richard Henry, Jr. Two Years Before the Mast: A Personal Narrative of Life at Sea. Ed. Thomas Philbrick. New York, NY: Penguin, 1981. Print.

Eagleton, Terry. Literary Theory: An Introduction. Minneapolis: University of Minnesota, 1983. Print.

Fiedler, Leslie A. Love and Death in the American Novel. Harmonsworth, Etc.: Penguin, 1984. Print.

Finseth, Ian. "Geographic Consciousness in the American Slave Narrative.” American Literary Geographies: Spatial Practice and Cultural Production, 1500-1900. Ed. Martin Brückner and Hsuan L. Hsu. Newark: University of Delaware, 2007. 23658. Print.

Foster, John. “A Map of New England.” The Present State of New-England. By William Hubbard. Massachusetts Maps. The Massachusetts Historical Society. Web. 1 Jun. 2015.

Frank, Frederick S., and Diane L. Hoeveler. Introduction. The Narrative of Arthur Gordon Pym of Nantucket. By Edgar A. Poe. Peterborough, Ont.: Broadview, 2010. 11-36. Print.

Giles, Paul. Antipodean America: Australasia and the Constitution of U. S. Literature. Oxford: Oxford UP, 2013. Print.

Halpern, Faye. "In Defense of Reading Badly: The Politics of Identification in 'Benito Cereno,' 'Uncle Tom's Cabin,' and Our Classrooms.” College English 70.6 (2008): 551-77. JSTOR. Web. 08 Mar. 2015.

Harvey, Bruce A. American Geographics: U.S. National Narratives and the Representation of the Non-European World, 1830-1865. Stanford, CA: Stanford UP, 2001. Print.

Hogle, Jerrold E. The Cambridge Companion to Gothic Fiction. Cambridge: Cambridge UP, 2002. Print.

Hutchisson, James M., ed. Edgar Allan Poe: Selected Poetry and Tales. Peterborough, Ont.: Broadview, 2012. Print.

Irving, Washington. The Legend of Sleepy Hollow and Other Writings. Ed. Peter Norberg and George Stade. New York: Barnes \& Noble Classics, 2006. Print.

Kane, Elisha K. The United States Grinnell Expedition in Search of Sir John Franklin: A Personal Narrative. Boston: Phillips, Sampson, 1857. Google Books. 5 May 2009. Web. 30 Apr. 2015.

King, Gilbert. "The True-Life Horror That Inspired Moby-Dick.” Smithsonian History. Smithsonian Institution, 1 Mar. 2013. Web. 21 Apr. 2014.

Kopley, Richard. Poe's Pym: Critical Explorations. Durham: Duke UP, 1992. Print.

Liu, Shengli. "Merleau-Ponty's Phenomenology of Space: Preliminary Reflection on an Archaeology of Primordial Spatiality." The 3rd BESETO Conference of Philosophy: 131-40. Web. 
Lovecraft, H. P. “The Colour Out of Space.” 1927. The H.P. Lovecraft Archive. 20 Aug. 2009. Web. 10 Nov. 2015.

Marx, Leo. The Machine in the Garden: Technology and the Pastoral Ideal in America. New York: Oxford UP, 1964. Print.

Melville, Herman. Benito Cereno. Ed. Wyn Kelley. Boston: Bedford/St. Martins, 2008. Print.

Paravisini-Gerbert, Lizabeth. "Colonial and Postcolonial Gothic: the Carribean.” The Cambridge Companion to Gothic Fiction. Ed. Jerrold Hogle. Cambridge: Cambridge UP, 2002. 229-57. Print.

Poe, Edgar A. "From a Review of Nathaniel Hawthorne's Twice-Told Tales.” Edgar Allan Poe: Selected Poetry and Tales. Ed. James M. Hutchisson. Peterborough, Ont.: Broadview, 2012. 525-27. Print.

---. The Narrative of Arthur Gordon Pym of Nantucket. Ed. Frederick S. Frank and Diane L. Hoeveler. Peterborough, Ont.: Broadview, 2010. Print.

---. “The Philosophy of Composition.” Edgar Allan Poe: Selected Poetry and Tales. Ed. James M. Hutchisson. Peterborough, Ont.: Broadview, 2012. 502-13. Print.

Radcliffe, Ann Ward. A Sicilian Romance. Ed. Alison Milbank. Oxford: Oxford UP, 2008. Print.

Savoy, Eric. "The Rise of American Gothic.” The Cambridge Companion to Gothic Fiction. Ed. Jerrold Hogle. Cambridge: Cambridge UP, 2002. 167-88. Print.

Sawin, Mark M. Raising Kane: Elisha Kent Kane and the Culture of Fame in Antebellum America. Philadelphia: American Philosophical Society, 2008. Print.

Shelley, Mary Wollstonecraft. Frankenstein: The 1818 Text, Contexts, Criticism. Ed. J. Paul Hunter. 2nd ed. New York: W.W. Norton, 2012. Print. Norton Critical Editions.

Spufford, Francis. I May Be Some Time: Ice and the English Imagination. New York: St. Martin's, 1997. Print.

Spurr, David. The Rhetoric of Empire: Colonial Discourse in Journalism, Travel Writing, and Imperial Administration. Durham: Duke UP, 1993. Print.

Stowe, Harriet Beecher. Uncle Tom's Cabin. Ed. Kathryn Kish Sklar. New York: Library of America, 2010. Print.

Tennenhouse, Leonard. The Importance of Feeling English: American Literature and the British Diaspora, 1750-1850. Princeton: Princeton UP, 2007. Print.

Toal, Catherine. “'Some Things Which Could Never Have Happened’: Fiction, Identification, and 'Benito Cereno'” Nineteenth-Century Literature 61.1 (2006): 32-66. JSTOR. Web. 08 Mar. 2015.

Trigg, Dylan. The Memory of Place: a Phenomenology of the Uncanny. Athens: Ohio UP, 2011. Print. 
Trouillot, Michel-Rolph. Silencing the Past: Power and the Production of History. Boston, MA: Beacon, 1995. Print.

Wilde, Oscar. The Picture of Dorian Gray. 1891. Ed. Michael P. Gillespie. Norton Critical Edition. 2nd ed. New York: W.W. Norton, 2007. Print.

Winthrop, John. "The City upon a Hill." John Winthrop's City upon a Hill, 1630. Web. 14 Nov. 2015. 